Western Washington University

Western CEDAR

2010

\title{
Recent and Future Warm Extreme Events and High-mountain Slope Stability
}

C. Huggel

N. Salzmann

S. Allen

Jacqueline Caplan-Auerbach

Western Washington University, jackie.caplan-auerbach@wwu.edu

L. Fischer

See next page for additional authors

Follow this and additional works at: https://cedar.wwu.edu/geology_facpubs

Part of the Geology Commons

\section{Recommended Citation}

Huggel, C.; Salzmann, N.; Allen, S.; Caplan-Auerbach, Jacqueline; Fischer, L.; Haeberli, W.; Larsen, C.; Schneider, D.; and Wessels, R., "Recent and Future Warm Extreme Events and High-mountain Slope Stability" (2010). Geology Faculty Publications. 42.

https://cedar.wwu.edu/geology_facpubs/42 
Authors

C. Huggel, N. Salzmann, S. Allen, Jacqueline Caplan-Auerbach, L. Fischer, W. Haeberli, C. Larsen, D. Schneider, and R. Wessels 


\section{PHILOSOPHICAL TRANSACTIONS

\section{Recent and future warm extreme events and high-mountain slope stability}

C. Huggel, N. Salzmann, S. Allen, J. Caplan-Auerbach, L. Fischer, W. Haeberli, C. Larsen, D. Schneider and R. Wessels

Phil. Trans. R. Soc. A 2010 368, 2435-2459

doi: $10.1098 /$ rsta.2010.0078

\section{References}

Rapid response

Subject collections

Email alerting service
This article cites 37 articles

http://rsta.royalsocietypublishing.org/content/368/1919/2435.ful I.html\#ref-list-1

Respond to this article

http://rsta.royalsocietypublishing.org/letters/submit/roypta;368/ $1919 / 2435$

Articles on similar topics can be found in the following collections

$$
\text { climatology (58 articles) }
$$

glaciology ( 12 articles)

Receive free email alerts when new articles cite this article - sign up in the box at the top right-hand corner of the article or click here

To subscribe to Phil. Trans. R. Soc. A go to:

http://rsta.royalsocietypublishing.org/subscriptions 


\section{Recent and future warm extreme events and high-mountain slope stability}

By C. Huggel ${ }^{1, *}$, N. Salzmann ${ }^{1,2}$, S. Allen $^{3,4}$, J. CAplan-Auerbach $^{5}$,

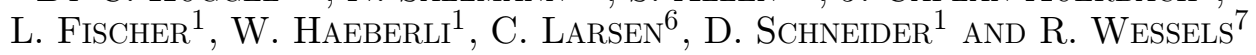

${ }^{1}$ Department of Geography, University of Zurich, Switzerland

${ }^{2}$ Department of Geosciences, University of Fribourg, Switzerland

${ }^{3}$ Department of Geography, University of Canterbury, Christchurch, New Zealand

${ }^{4}$ Climate and Environmental Physics, Physics Institute, University of Bern, Switzerland

${ }^{5}$ Geology Department, Western Washington University, Bellingham, WA, USA

${ }^{6}$ Geophysical Institute, University of Alaska, Fairbanks, AK, USA

${ }^{7}$ US Geological Survey, Alaska Science Center-Alaska Volcano Observatory, Anchorage, AK, USA

The number of large slope failures in some high-mountain regions such as the European Alps has increased during the past two to three decades. There is concern that recent climate change is driving this increase in slope failures, thus possibly further exacerbating the hazard in the future. Although the effects of a gradual temperature rise on glaciers and permafrost have been extensively studied, the impacts of short-term, unusually warm temperature increases on slope stability in high mountains remain largely unexplored.

We describe several large slope failures in rock and ice in recent years in Alaska, New Zealand and the European Alps, and analyse weather patterns in the days and weeks before the failures. Although we did not find one general temperature pattern, all the failures were preceded by unusually warm periods; some happened immediately after temperatures suddenly dropped to freezing.

We assessed the frequency of warm extremes in the future by analysing eight regional climate models from the recently completed European Union programme ENSEMBLES for the central Swiss Alps. The models show an increase in the higher frequency of high-temperature events for the period 2001-2050 compared with a 1951-2000 reference period. Warm events lasting 5, 10 and 30 days are projected to increase by about 1.5-4 times by 2050 and in some models by up to 10 times.

Warm extremes can trigger large landslides in temperature-sensitive high mountains by enhancing the production of water by melt of snow and ice, and by rapid thaw. Although these processes reduce slope strength, they must be considered within the local geological, glaciological and topographic context of a slope.

Keywords: warm extremes; avalanches; slope instabilities

*Author for correspondence (christian.huggel@geo.uzh.ch).

One contribution of 15 to a Theme Issue 'Climate forcing of geological and geomorphological hazards'. 


\section{Introduction}

There is increasing concern that rising air temperatures could affect slope stability in high-mountain areas owing to decay of glaciers and degradation of permafrost (Haeberli et al. 1997; Gruber \& Haeberli 2007; Huggel et al. 2008a,b). Large rock or ice avalanches can be destructive and far reaching, especially when they impact lakes and trigger large outburst floods (Clague \& Evans 2000; Huggel et al. 2004; Kääb et al. 2005; Haeberli \& Hohmann 2008).

While there is a long tradition of research on alpine ice avalanches (Heim 1932; Alean 1985; Röthlisberger 1987), research on rock-slope instability related to permafrost degradation is a more recent development (Wegmann et al. 1998; Gruber \& Haeberli 2007; Harris et al. 2009). Indications of possible effects of climate change on slope stability has come from an increasing number of large-size rock falls and rock avalanches from permafrost areas in the Alps over the past two decades (Barla et al. 2000; Fischer et al. 2006; Gruber \& Haeberli 2007; Fischer \& Huggel 2008; Sosio et al. 2008). Many of these events have not yet been studied in detail, and the causes and trigger processes are not adequately understood. However, understanding of the effects of longterm climate change on frozen rock slopes has been improved by numerical modelling of the distribution of subsurface temperatures in complex threedimensional topography in a warming climate (Noetzli et al. 2007; Fischer et al. submitted $a, b$ ). Furthermore, recent studies have shown that polythermal glaciers overlying frozen bedrock can induce thermal anomalies in the ground as deep as several tens of metres (Haeberli et al. 1997; Wegmann et al. 1998; Huggel et al. 2008a,b).

An aspect of high-mountain slope instability that has been little studied is the effect of extreme, short-lived temperature events as a potential trigger of rock and ice avalanches. The extreme heat wave in Europe in the summer of 2003 appears to have triggered numerous small rock falls $\left(10^{2}-10^{3} \mathrm{~m}^{3}\right)$, probably owing to rapid thawing and thickening of the active layer (Gruber et al. 2004a). And a very large rock-ice avalanche (approx. $5 \times 10^{7} \mathrm{~m}^{3}$ ) on Mount (Mt) Steller in Alaska in September 2005 occurred during unusually warm weather, with temperatures far above the freezing point (Huggel 2009). However, a detailed analysis of weather conditions during these events has not yet been completed. In addition, analysis of a larger sample of events is important for a better understanding of the impacts of current and future warm weather on slope stability, especially given that current projections indicate an increase in the number of extreme climatic events with high temperatures (Tebaldi et al. 2006; Meehl et al. 2007).

In this paper, we examine meteorological conditions leading up to several large rock and ice avalanches in south-central Alaska, the European Alps and the Southern Alps of New Zealand. We focus on the air-temperature history days and weeks before failure. Long-term ground surface and firn or ice temperatures, geology and topography are also considered, but are not the primary focus of the paper. Based on results from case studies, we define appropriate climatic indicators and use the recently completed ENSEMBLES regional climate model (RCM) runs for the central Alps to determine whether critically warm weather, which has the potential to trigger large slope failures, will occur more often in the future. For the analysis of meteorological and climatic conditions of case studies, 
we generally use reference time periods that vary according to the available climate records. For future projections, we consider the period 2001-2050, using the reference period of 1951-2000.

Conclusive statements on the impacts of extreme weather events on slope stability in high mountains cannot be made at this time because research on this topic is not far advanced and because slope stability in high mountains is controlled not only by thermal conditions but also, and particularly, by geology, topography and hydrology, all of which are highly interconnected (Fischer \& Huggel 2008). Also, other climate parameters, such as radiation, are important in complex, high-mountain topography (Salzmann et al. $2007 a, b$ ), and may play a role in triggering slope failure.

\section{Case studies}

\section{(a) Aoraki/Mount Cook, New Zealand}

Shortly after midnight on 14 December $1991,12 \times 10^{6} \mathrm{~m}^{3}$ of rock and ice detached from the east face of New Zealand's highest peak, Aoraki/Mt Cook (3754 $\mathrm{m}$ above sea level (a.s.l.)) (figure 1). The large rock-ice avalanche narrowly missed an occupied alpine hut, completely scoured and entrained a steep icefall, and came to rest after running approximately $70 \mathrm{~m}$ up an opposing valley wall. The avalanche travelled $7.5 \mathrm{~km}$, and in the process bulked up to a total volume estimated at $60-80 \times 10^{6} \mathrm{~m}^{3}$ with entrained snow and ice (figure 2; McSaveney 2002). It lowered the summit of Aoraki/Mt Cook and continues to significantly affect the flow of Tasman Glacier (Quincey \& Glasser 2009). Large slope failures are common in New Zealand's Southern Alps, where Carboniferous-Cretaceous greywacke is being rapidly uplifted along an active tectonic plate margin (McSaveney 2002; Cox \& Allen 2009). Rapid twentieth-century glacial recession is likely implicated in some large landslides in this region (McSaveney 2002); it has removed lateral support provided to adjacent steep slopes and exposed previously thermally insulated surfaces to mechanical and thermal erosion. Recently, researchers have begun to consider the importance of temperature regimes and permafrost warming in triggering smaller slope failures $\left(10^{4}-10^{5} \mathrm{~m}^{3}\right)$ during the warm dry summer of 2007-2008 (Allen et al. 2009).

The Aoraki/Mt Cook rock-ice avalanche initiated with the failure of a large, east- to southeast-facing rock mass that supported the approximately $15 \mathrm{~m}$ thick summit ice cap. Foliation in closely jointed greywacke and argillite dip steeply in the summit area, and the approximately $60 \mathrm{~m}$ deep failure scar exposed a heavily fractured and dilated rock mass of poor quality (McSaveney 2002). The detachment zone dipped $50^{\circ}-60^{\circ}$ and included a small hanging glacier that was partially removed during the failure.

The nearest available climate data come from Mt Cook Village approximately $16 \mathrm{~km}$ south of, and approximately $3000 \mathrm{~m}$ below, the Aoraki/Mt Cook summit. High orographic precipitation in this region (greater than $10 \mathrm{~m}$ water equivalent precipitation per year) favours the use of a humid free-air lapse rate $\left(0.0055^{\circ} \mathrm{C} \mathrm{m}^{-1}\right)$ to extrapolate air-temperature data to the detachment zone of the landslide. Based on data for the years 1960-1990, mean annual air temperature (MAAT) at the base of the detachment zone $(2900 \mathrm{~m})$ is estimated to be $-3.1^{\circ} \mathrm{C}$, decreasing to $-7.8^{\circ} \mathrm{C}$ towards the mountain summit $(3754 \mathrm{~m})$. This estimate 


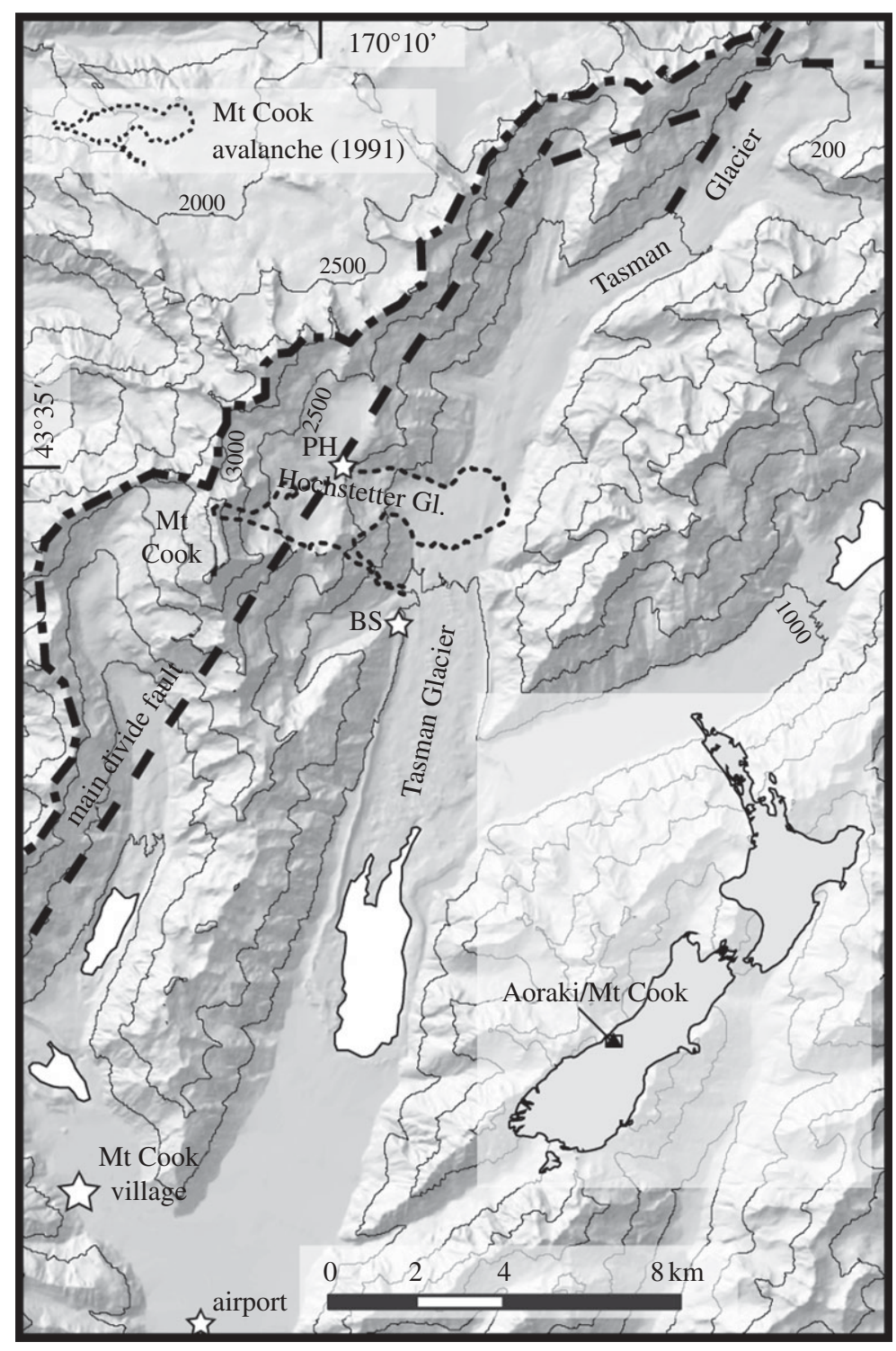

Figure 1. Map showing location of the Aoraki/Mt Cook avalanche (dashed line) and the meteorological station at Mt Cook village (PH: Plateau Hut, BS: Ball Shelter).

is generally supported by the recent rockwall temperature measurements and solar-radiation-based modelling of mean annual ground surface temperature (MAGST) (Allen et al. 2009), modified here to incorporate the same lapse rate of $0.0055^{\circ} \mathrm{C} \mathrm{m}^{-1}$. MAGST within the Mt Cook detachment zone ranges from 0 to $-6.3^{\circ} \mathrm{C}$ at $3754 \mathrm{~m}$, with variations depending on elevation and aspect (Allen et al. 2009). Extrapolated MAGST and MAAT values suggest that most of the detachment zone supported cold permafrost; only the lowermost part of the detachment zone was likely in a warm or marginal state. 


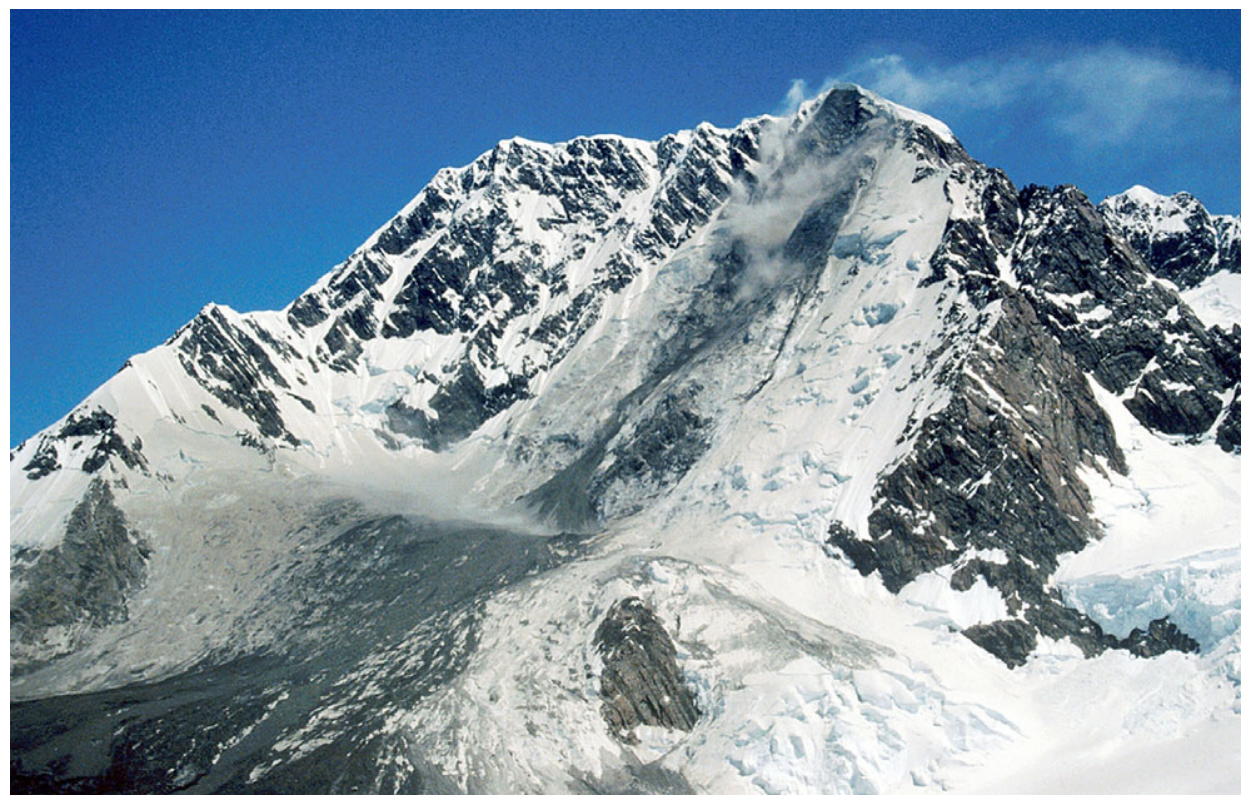

Figure 2. Rock-ice detachment from Mt Cook $(3754 \mathrm{~m}), 14$ December 1991. The failure reduced the elevation of New Zealand's highest mountain by approximately $10 \mathrm{~m}$. Photo taken by I. Owens on 16 December 1991.

Following a particularly cold winter, the summit of Aoraki/Mt Cook experienced repeated periods of daily maximum temperatures far above $0^{\circ} \mathrm{C}$ in November and early December of 1991. Subsequent cooling brought temperatures to below seasonal averages (figure 3). During the week immediately before the rock-ice avalanche, temperatures warmed again, culminating in exceptional, estimated daily maximum temperatures of 14.4 and $9.7^{\circ} \mathrm{C}$ at, respectively, the base and top of the detachment zone on 11 December. Although early during the summer, these extreme temperatures were within the warmest 92nd percentile of maximum daily summer temperatures as recorded for the Mt Cook Village meteorological station for the period 1961-1990 (figure 4). Prolonged melting occurred throughout the summit area including the detachment zone, followed by rapid cooling to subfreezing temperatures $24 \mathrm{~h}$ prior to the failure.

Given the presence of a small glacier and an extensive cover of seasonal snow within the detachment zone, the unusually warm temperatures would have melted firn and produced abundant melt water. McSaveney (2002) suggested that refreezing of this melt water on a clear cold night may have been sufficient to trigger the failure. Freezing could have blocked the movement of melt water in the bedrock, causing rapid pore-pressure variations.

Because the lower part of the detachment zone was probably characterized by warm or discontinuous permafrost, melt water may have penetrated discontinuities in bedrock that were previously filled with ice. The rock-ice avalanche occurred after several years of the above average annual temperatures (figure 5), during which ice-filled discontinuities may have thawed. 


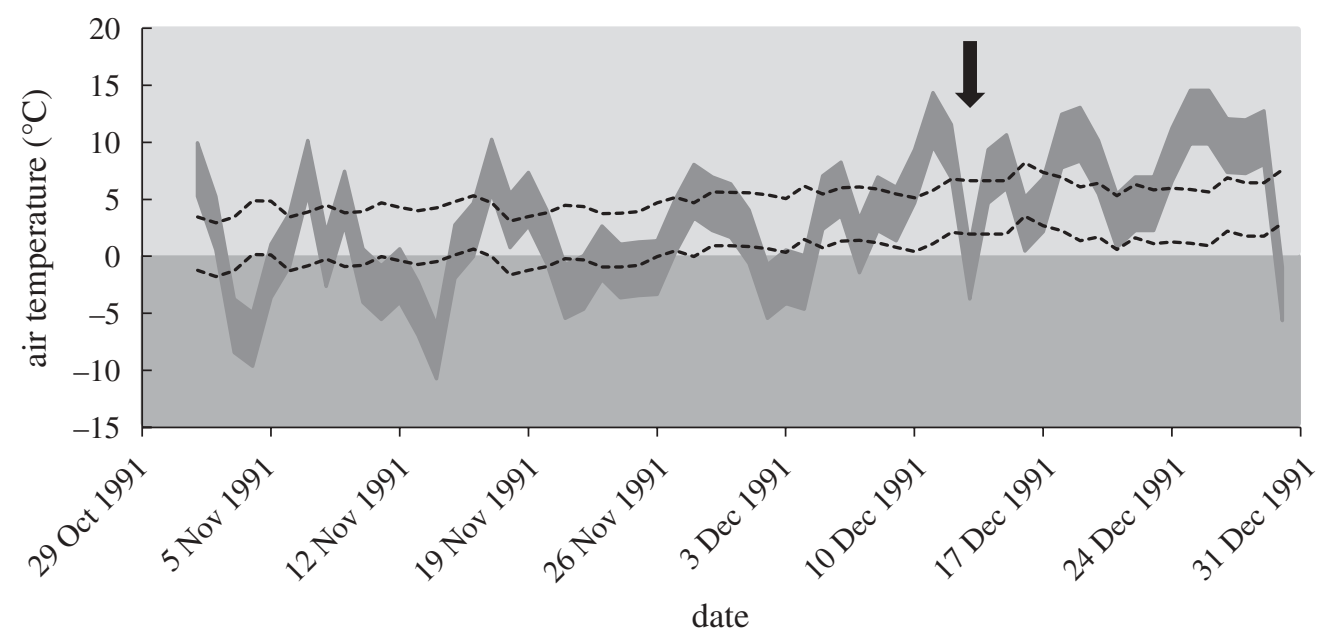

Figure 3. Daily maximum air-temperature range between the top (3754 m) and bottom (2900 m) of the Mt Cook rock-ice detachment zone, extrapolated from Mt Cook Village $(765 \mathrm{~m})$. Dashed lines indicate the maximum daily temperature range between these same elevations, averaged for the period 1960-1990. The time of the failure is indicated by the black arrow.

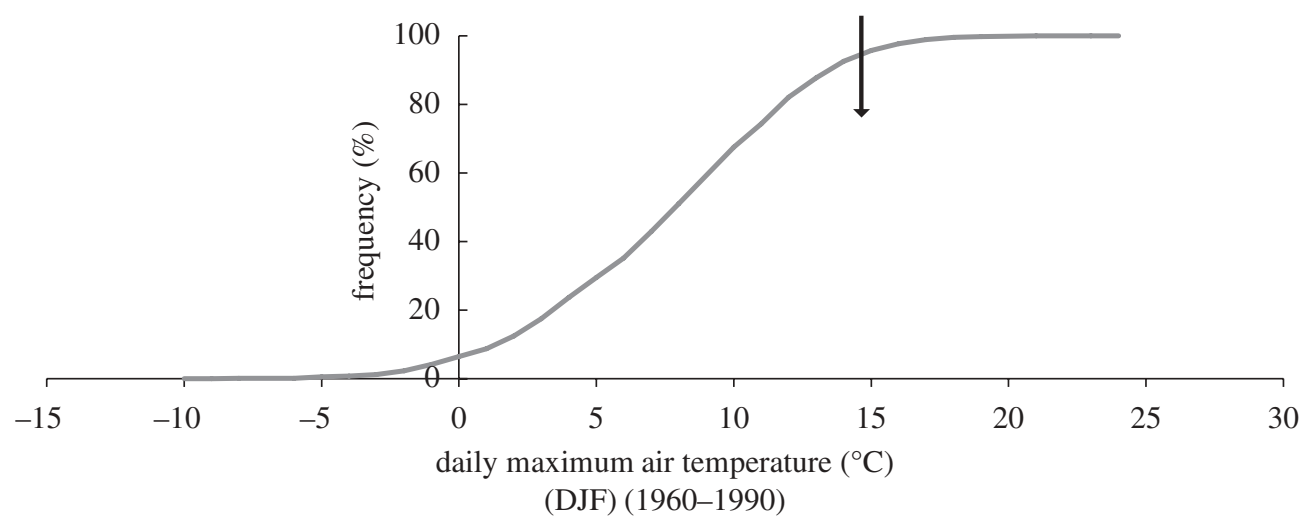

Figure 4. Cumulative frequency distribution of daily maximum temperatures (1960-1990) at $2900 \mathrm{~m}$ on Mt Cook during the summer months of December, January and February (DJF). The maximum daily temperature of $14.4^{\circ} \mathrm{C}$ (arrow) preceding the Mt Cook rock-ice failure corresponds to the 92nd percentile.

\section{(b) Alaska case histories}

Some researchers have highlighted the recent widespread landsliding in several mountain ranges in Alaska, some related to earthquakes (Jibson et al. 2006), others related to volcanic activity (Caplan-Auerbach \& Huggel 2007; Huggel et al. 2007) and still others with no obvious external trigger (Arsenault \& Meigs 2005; 


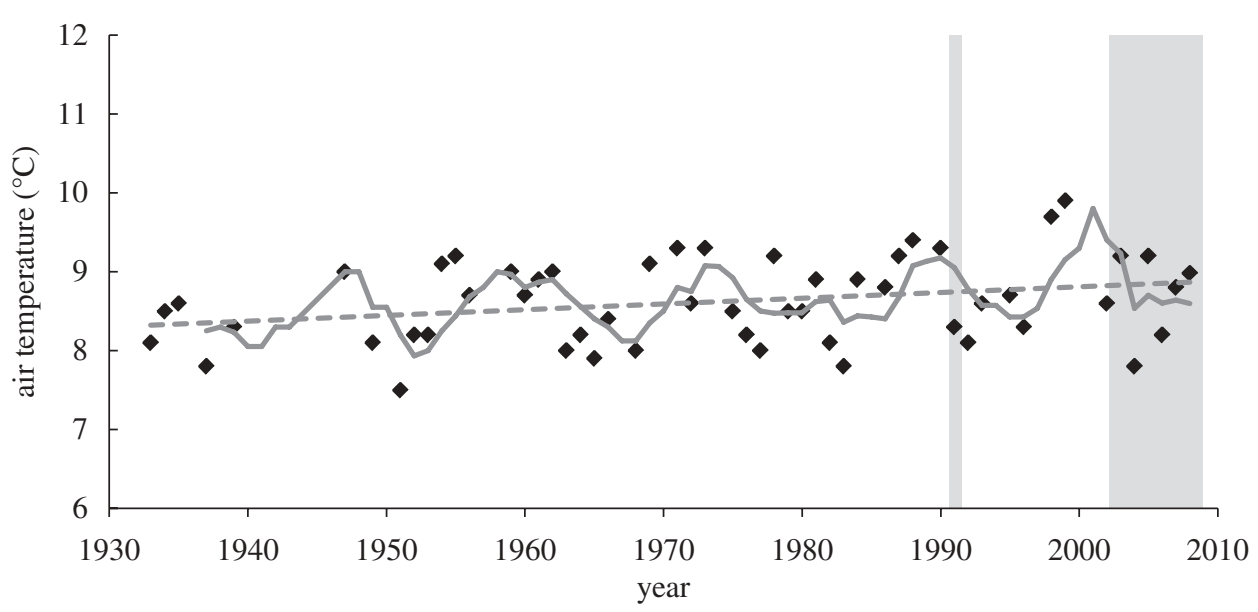

Figure 5. Mean annual air temperature (MAAT) trends at Mt Cook Village $(765 \mathrm{~m})$. Shaded boxes indicate the time of the $1991 \mathrm{Mt}$ Cook rock-ice avalanche, and a recent cluster of smaller slope failures since 2002 (see Cox \& Allen 2009 and Allen et al. 2009 for more details). Filled diamonds, MAAT; grey line, 5 year moving average; dashed line, linear trend.

Huggel et al. 2008a,b). Our focus here is a series of recent, large rock and ice avalanches in the Bagley Ice Field region of southeast Alaska that have intriguing relations to air- and ground-temperature conditions.

\section{(i) Mount Steller 2005}

The largest of a number of rock and ice avalanches in the Bagley Ice Field occurred at Mt Steller on 14 September 2005. Mt Steller (3236 m a.s.l.) is part of the Waxell Ridge, which separates the Bagley Ice Field from Bering Glacier (figure 6). The avalanche initiated from the south face of Mt Steller, close to the summit. Observations made during an overflight a day after the failure suggest that the initial failure was in bedrock, between 2500 and $3100 \mathrm{~m}$ a.s.l. The south flank of Mt Steller is formed of tertiary sedimentary rocks that dip subparallel to the slope. Significant parts of the ice mass on the summit ridge also broke off or were entrained by the rock-slope failure. The initial volume of failed rock has been estimated to be $10-20 \times 10^{6} \mathrm{~m}^{3}$; an additional $3-4.5 \times 10^{6} \mathrm{~m}^{3}$ of glacier ice also failed (Huggel et al. 2008a,b). The avalanche travelled $9 \mathrm{~km}$ horizontally and $2430 \mathrm{~m}$ vertically. It entrained up to a few tens of millions of cubic metres of glacier ice, snow and debris along its path, resulting in a total volume of $40-60 \times 10^{6} \mathrm{~m}^{3}$.

Evidence of water flowing on exposed bedrock in the detachment zone immediately after the failure raised the question to what extent the slope failure was triggered by melting of glacier ice or thawing of permafrost. Analysis of daily temperatures derived from radiosonde measurements at Yakutat, Alaska indicate that temperatures in the summit region of Mt Steller were above freezing for about 10 days before the avalanche (Huggel 2009). An assessment of MAGSTs indicates that permafrost on the south face of Mt Steller should be cold. However, modelling studies show that the summit ice cap is probably polythermal, in which case, it induced a thermal anomaly to the ground, warming the underlying bedrock by several ${ }^{\circ} \mathrm{C}$ (Huggel et al. 2008a). 


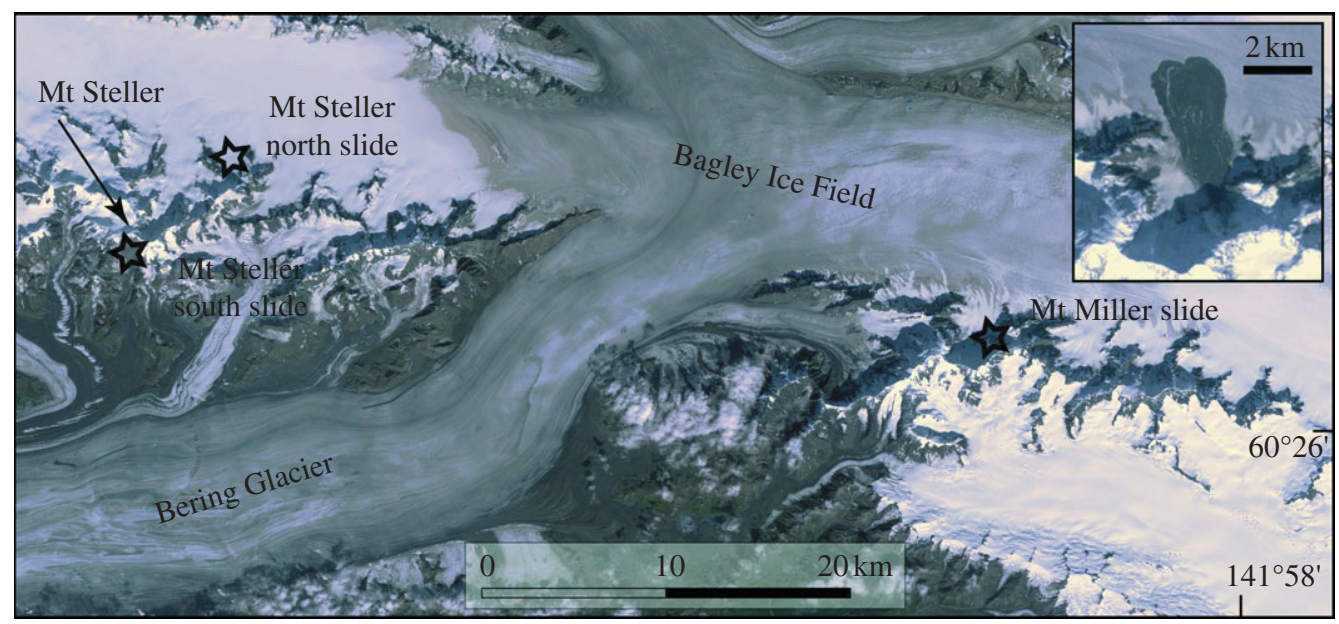

Figure 6. Landsat satellite image (3 September 2007) showing the Bagley Ice Field regions and the locations of the landslides in 2005 and 2008.

Although the trigger of the avalanche is not known with certainty, the thermal state of the hanging glacier and bedrock, in combination with the extremely warm air temperatures, could have generated melt water that infiltrated fractures in the summit rock mass, destabilizing it. Melt water flowing at the base of the summit glacier probably reduced the shear strength of the rock mass and promoted its failure.

\section{(ii) Mount Steller 2008}

Two landslides occurred from Mt Steller in July 2008 (figure 6). One detached from the north face of the ridge that extends east from the summit. The north flank of Mt Steller is heavily glacierized, with few bedrock outcrops (figures 7 and 8). The landslide initiated in steep ice about $100 \mathrm{~m}$ below the summit ridge at $c a 2350 \mathrm{ma}$ a.s.l. The failure extended into bedrock beneath the ice. High-resolution satellite images taken on 21 June 2008 show a developing slope instability in the bedrock beneath the steep glaciers on the north face of the mountain, as well as a precursory smaller rock avalanche (figure 8). The main landslide occurred before 9 July when an overview flight of Mt Steller was made (figure 9).

It is difficult to assess from post-event imagery the depth of the detachment surface. The upper part of the scarp has a near-vertical failure plane in the sedimentary rock. The exposed rock of the scarp is highly jointed and several large joint systems run across the scarp. Given the evidence for instabilities in bedrock prior to the main failure, it is likely that the landslide had its origin in a rock-slope instability, rather than in glacier ice. Nevertheless, thermal instability in rock at the base of the ice may have played an important role (Haeberli et al. 1997; Huggel 2009).

We estimate the volume of ice that failed and became entrained in the avalanche to be $400000-700000 \mathrm{~m}^{3}$, based on a scarp length of $400 \mathrm{~m}$ and width of $200 \mathrm{~m}$ and an estimated ice thickness of $5-10 \mathrm{~m}$ (figure 8). The amount of 


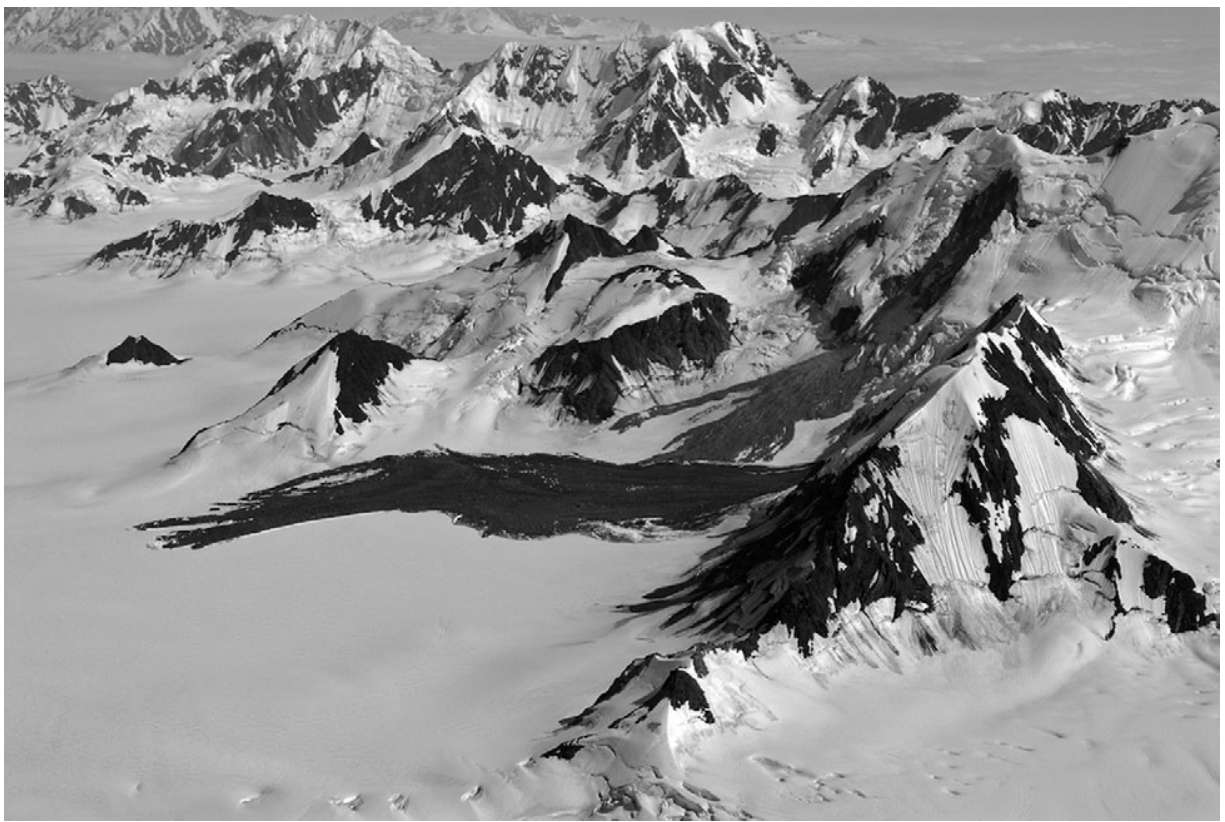

Figure 7. Two rock-ice avalanches from Mt Steller region running out on the Bagley Ice Field. View is towards southeast. Photo taken by C. Larsen on 24 July 2008.
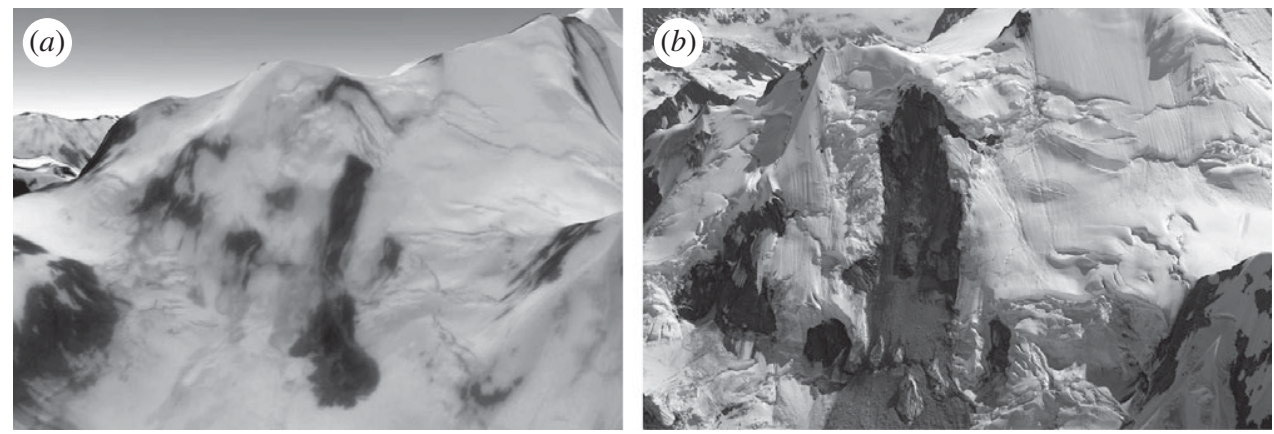

Figure 8. (a) Three-dimensional view based on a high-resolution satellite image of the source area of the 2008 Mt Steller rock-ice avalanche taken on 21 June 2008 (retrieved from GoogleEarth), showing a precursory rock slide. (b) The main failure (24 July 2008, photo by C. Larsen).

bedrock that failed is difficult to assess, but a rough estimate can be derived from the avalanche deposit volume, which is about $1 \times 10^{6} \mathrm{~m}^{3}$. Deposits showed predominantly shattered rock with single large blocks of several metres in diameter.

A second landslide occurred at about $1950 \mathrm{~m}$ a.s.l., about $80 \mathrm{~m}$ below the crest of a rock ridge on the northeast-facing flank of Mt Steller and less than $2 \mathrm{~km}$ from the first landslide. It overrode the distal part of deposits of the first avalanche. The rock slope failed in two stages: a larger failure occurred before 9 July and 


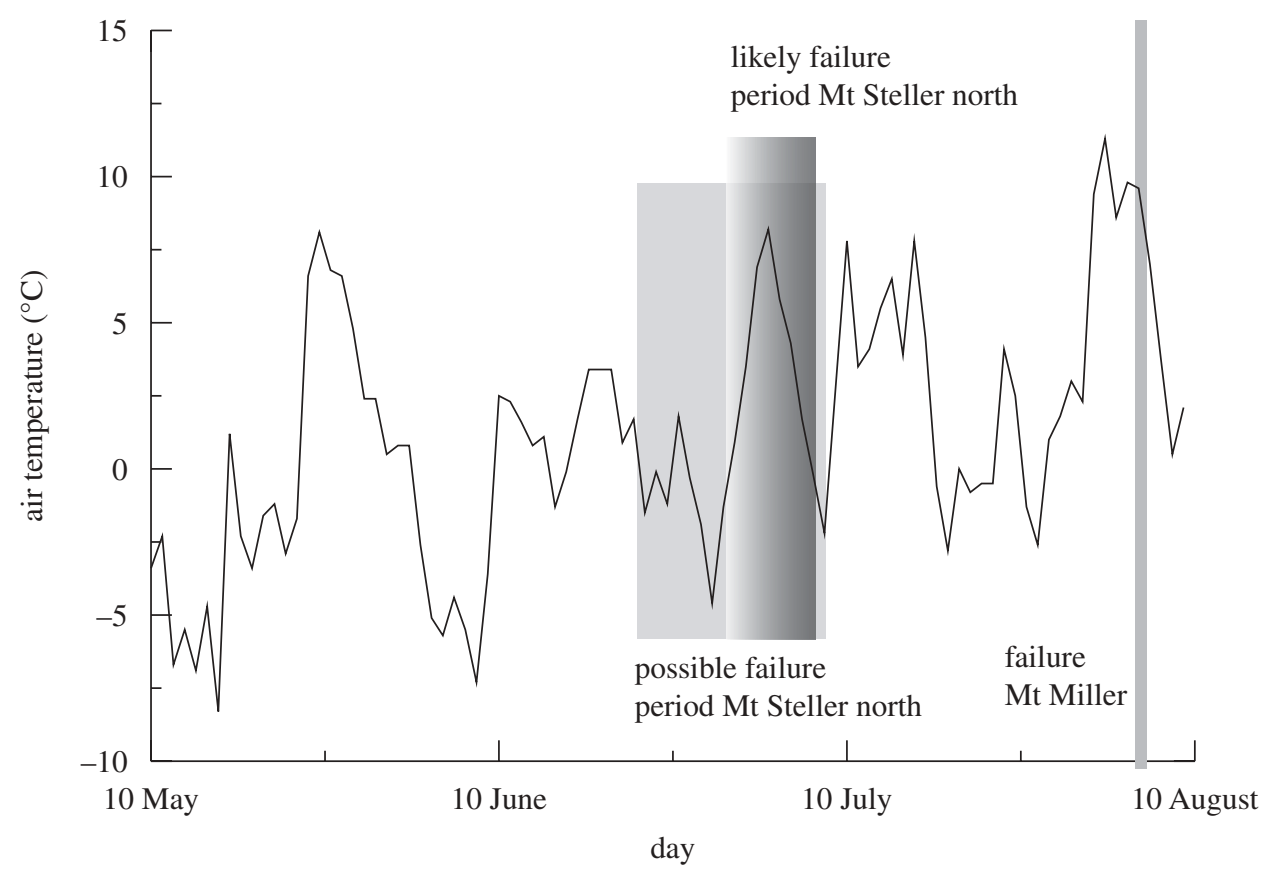

Figure 9. Air-temperature record for the period between 10 May and 10 August 2008, based on radiosonde data from Yakutat, extrapolated to $2000 \mathrm{~m}$ a.s.l., the approximate elevation of the failure zones of the Mt Steller north and Mt Miller landslides. The Mt Miller slide was on 6 August 2008, while the exact day of failure of the Mt Steller north landslides is unknown.

involved the upper part of the failure zone; a smaller one involved detachment of a rock mass from the lower part of the failure zone and occurred between 20 and 24 July. The maximum runout of the landslide is $2.2 \mathrm{~km}$, and its deposit area is about $0.45 \mathrm{~km}^{2}$. The estimated volume is $1-1.5 \times 10^{6} \mathrm{~m}^{3}$, based on field observations of deposit thickness of $1-3$ and $3-5 \mathrm{~m}$, respectively, in the lower and middle parts of the deposit. Only small amounts of glacier ice were involved in this landslide.

Mean annual rock surface temperatures at the 2008 failure sites on the north flank of Mt Steller can be estimated using the thermal approach of Huggel et al. $(2008 a)$. MAAT derived from troposphere temperature data provided by the Yakutat radiosonde, $220 \mathrm{~km}$ southeast of the landslides, was used, together with a vertical gradient of $0.0065^{\circ} \mathrm{C} \mathrm{m}^{-1}$ (Huggel et al. 2008a), to calculate MAGST. MAAT derived from the radiosonde data was increased by $1^{\circ} \mathrm{C}$ for northern aspects and by $3^{\circ} \mathrm{C}$ for southern aspects (Haeberli et al. 2003; Gruber et al. 2004b; Huggel et al. $2008 a$ ). The analysis yields MAGST of $-2.5^{\circ} \mathrm{C}$ at $2000 \mathrm{~m}$ a.s.l. on the north-facing slope at the location of the first landslide (figure 10). Exposed bedrock surface temperatures at the location of the first slide may have been in the range of -1.5 to $-3.5^{\circ} \mathrm{C}$. However, the failure zone was largely covered by glacier ice, which was likely polythermal given the prevailing air temperatures. Thus, at least some parts of the failure area were close to the freezing point. Modelling studies have shown that the thermal effect of polythermal glaciers 


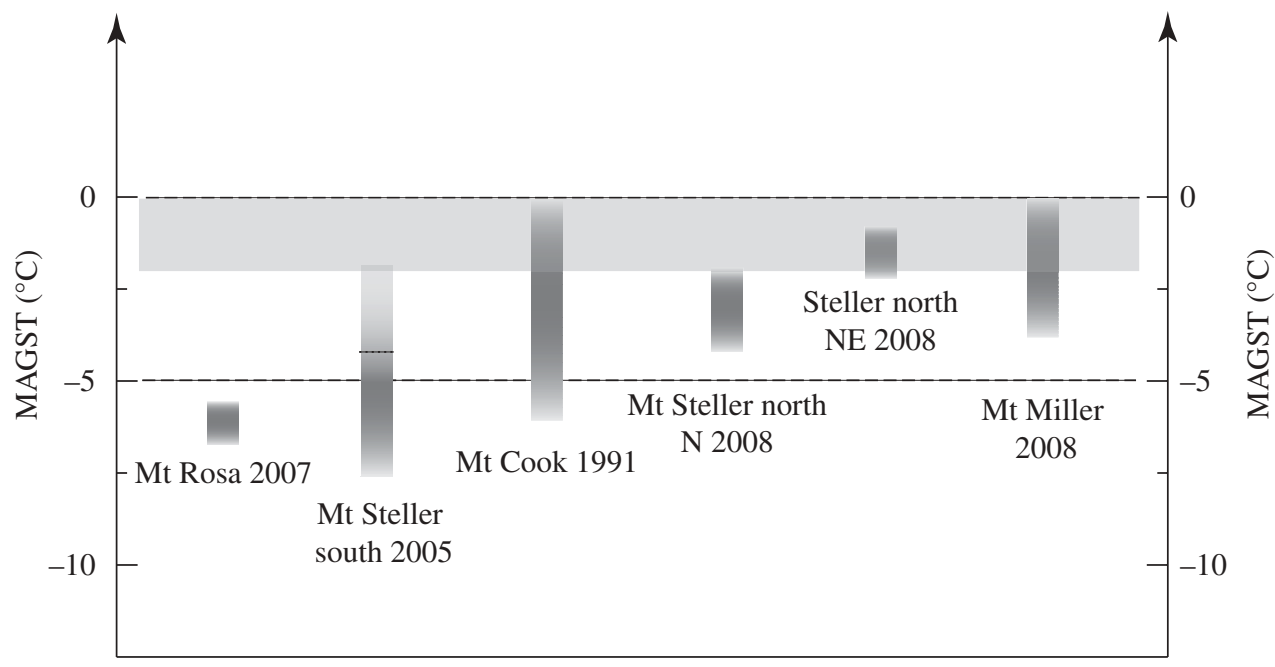

Figure 10. Mean annual ground surface temperatures (MAGST), estimated for the six rock and ice avalanches presented in this study. The initiation zones of the landslides ranged from 2000 to $4000 \mathrm{~m}$ a.s.l. The thermal range for the Mt Steller south landslide is extended to temperatures up to $-2^{\circ} \mathrm{C}$, considering the influence of its polythermal summit glacier. The grey horizontal bar indicates MAGST of -2 to $0^{\circ} \mathrm{C}$, a thermal zone thought to be especially susceptible to slope failure.

on the underlying bedrock can be complex (Haeberli et al. 1997; Wegmann et al. 1998; Huggel et al. 2008a,b), but water was probably present at the base of the glacier, and possibly within fractures in the underlying rock. Close-up photographs of the failure zone, a few days after the avalanche show extensive water flowing on the scarp that, in part, probably was produced by melting of ice and snow, but may to a lesser extent have its origin in rock fractures. Liquid water has similarly been observed on exposed detachment surfaces of landslides at high elevations in the Alps (Gruber \& Haeberli 2007; Huggel 2009; Fischer et al. submitted a).

The inferred thermal conditions at the site of the second landslide are different. The upper end of the failure zone is some $300 \mathrm{~m}$ lower than that at the first site, and the site has a northeast aspect. Based on the analysis outlined above, MAGST of the failure zone of this landslide may be between -1 and $-2^{\circ} \mathrm{C}$, with warm permafrost close to thawing. Here, bedrock is largely exposed rather than covered by glacier ice, although the thermal effect of the snow cover must also be taken into account. As in the case of the first landslide, water was visible on the exposed scar and may have flown from rock fractures.

To assess the thermal effects of weather conditions days and weeks before the Mt Steller avalanches, we extrapolated $700 \mathrm{hPa}$ level temperatures (approx. $3000 \mathrm{~m}$ a.s.l.) of the Yakutat radiosonde to a $2000 \mathrm{~m}$ a.s.l. level, which is the height of the failure zones of the two landslides. The record shows an approximate 10 day period of very warm temperature (up to $8^{\circ} \mathrm{C}$ ) at the end of May (figure 9 ), temperature fluctuations around the freezing point in June, pronounced warming at the beginning of July with a maximum temperature greater than $8^{\circ} \mathrm{C}$ on 4 July, and a sudden drop in temperature, culminating in temperatures below $0^{\circ} \mathrm{C} 5$ days 


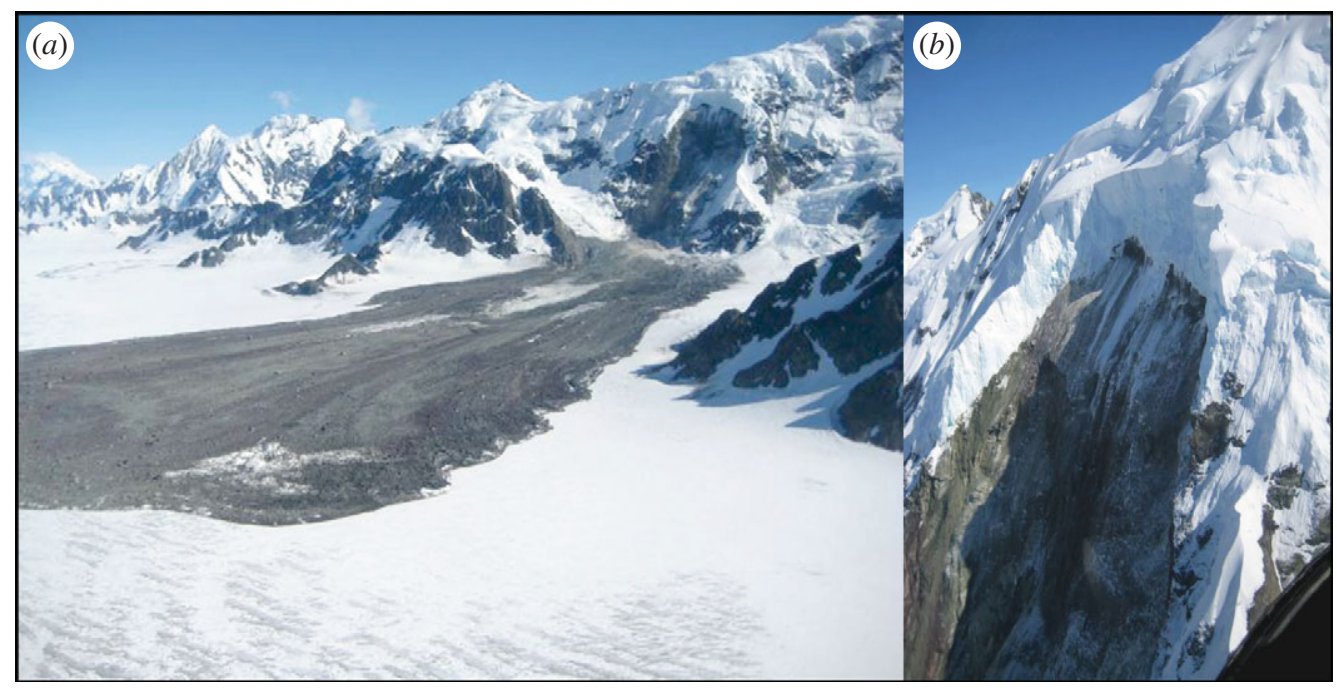

Figure 11. (a) The large rock-ice avalanche from the Mt Miller region on the Bagley Ice Field. (b) Close-up view of the failure zone showing the thickness of glacier ice involved in the rock-ice avalanche.

later. Only 2 days later, on 11 July, temperatures were again up to approximately $8^{\circ} \mathrm{C}$ (figure 9). If our analysis of the date of the landslide is correct (i.e. one to a few days before 9 July), failure occurred either during the very warm period with temperatures far above freezing, or during the sudden temperature drop at the end of the first week of July. The pattern is similar to that at Aoraki/Mt Cook leading up to the 1991 landslide.

\section{(iii) Mount Miller 2008}

A large rock-ice avalanche occurred on the north slope of a ridge near $\mathrm{Mt}$ Miller within 1 month of the 2008 Mt Steller failures (figure 6). The summit ridge elevation at the site of the landslilde is about $2400 \mathrm{~m}$, and the failure zone extends from about $2200 \mathrm{~m}$ to $1600 \mathrm{~m}$. The avalanche ran out $4.5 \mathrm{~km}$ onto the Bagley Ice Field, coming to rest at an elevation of as low as $1290 \mathrm{~m}$ (figure 11). The Fahrböschung (ratio of horizontal runout to vertical drop; $H / L$ ) is 0.2 , which is low but within the range of similarly sized ice and rock avalanches (Legros 2002; Huggel et al. 2007). The landslide was recorded at about 20.25 UTC (11.25 local time) on 6 August 2008, at a seismic station $10 \mathrm{~km}$ to the east of the slide. The site was visited a few days after the landslide, and photos of the failure and deposit were taken from the ground and air. The deposit had a mean thickness of $3-5 \mathrm{~m}$, which yields a total volume of $16-28 \times 10^{6} \mathrm{~m}^{3}$.

Inspection of the scarp confirmed that large amounts of glacier ice and bedrock were involved in the landslide, with initial failure probably being in bedrock. The steepest section of the scarp flank revealed $50-80 \mathrm{~m}$ of glacier ice overlying the exposed bedrock. The scarp extends several tens of metres into the bedrock that consists of relatively intact basalt. 
MAGST was estimated in the same way as for the Mt Steller landslides using the Yakutat radiosonde data, $180 \mathrm{~km}$ to the southeast of the landslide site. The failure zone is north-northwest-facing and therefore the MAGST of $-2.5^{\circ} \mathrm{C}$ at $2000 \mathrm{~m}$ a.s.l. determined for north-facing slope at Mt Steller should be applicable to Mt Miller. The range of MAGST of the failure zone (ca 2200$1800 \mathrm{~m}$ a.s.l.) is -3.7 to $-1.3^{\circ} \mathrm{C}$, suggesting that relatively warm permafrost conditions existed in the lower part of the zone. However, the exact elevation range of the failure zone is difficult to determine because significant snow and ice was entrained along the path. Even more difficult is the identification of the precise area where the failure initiated. Notwithstanding these difficulties, it is likely that areas at the transition of frozen to non-frozen bedrock were involved in the failure.

No liquid water was observed on the exposed bedrock of the Mt Miller landslide scarp at the time of the field visit, during which air temperatures were around the freezing point at the elevation of the scarp. Photographs taken 4 days after the landslide suggested that the upper end of the failure zone was frozen to the glacier bed.

We based our analysis of meteorological conditions days and weeks prior to the Mt Miller failure on an extrapolation of the $700 \mathrm{hPa}$ level temperatures from the Yakutat radiosonde to an elevation of $2000 \mathrm{~m}$, which we consider to represent thermal conditions in the middle to the upper part of the failure zone. Temperature increased from $-2.5^{\circ} \mathrm{C}$ on 27 July to over $11^{\circ} \mathrm{C}$ on 2 August 2008 (figure 9). This very warm period was maintained until the day of the failure on 6 August, but then dropped to freezing. The air-temperature data thus indicate that the entire slope where the landslide occurred was in a melting state for several days before failure.

The long-term effect of the glacier on the underlying bedrock must also be considered. Based on the long-term radiosonde record, MAAT at the elevation of the failed glacier is about $-5^{\circ} \mathrm{C}$, and accordingly firn temperatures should be temperate. These are conditions where seasonal melting is possible and latent-heat effects from refreezing of melt water can significantly warm the ice (Suter et al. 2001). Thermal modelling studies have shown that the thermal anomaly produced by freezing of water at the base of a glacier can penetrate tens of metres into underlying bedrock (Wegmann et al. 1998; Huggel et al. 2008a).

\section{(c) Monte Rosa, Alps}

The east face of Monte Rosa extends from about $2200 \mathrm{~m}$ to over $4600 \mathrm{~m}$ a.s.l., and was the site of two spectacular avalanches in 2005 and 2007 (Fischer et al. 2006). The slope increases upward, reaching greater than $55^{\circ}$ in the exposed gneissic bedrock sections and greater than $40^{\circ}$ in the sections with glaciers (figure 12). Studies based on sequential historical photographs have shown that the ice cover on the east face of the mountain changed a little during the twentieth century until about 1980, when it began to rapidly decrease (Haeberli et al. 2002; Fischer et al. submitted $b$ ). Slope instability involving both ice and rock increased around 1990 and has continued to the present (Fischer et al. 2006). Instability culminated in two large avalanches, one on 25 August 2005, and the other on 27 April 2007. 


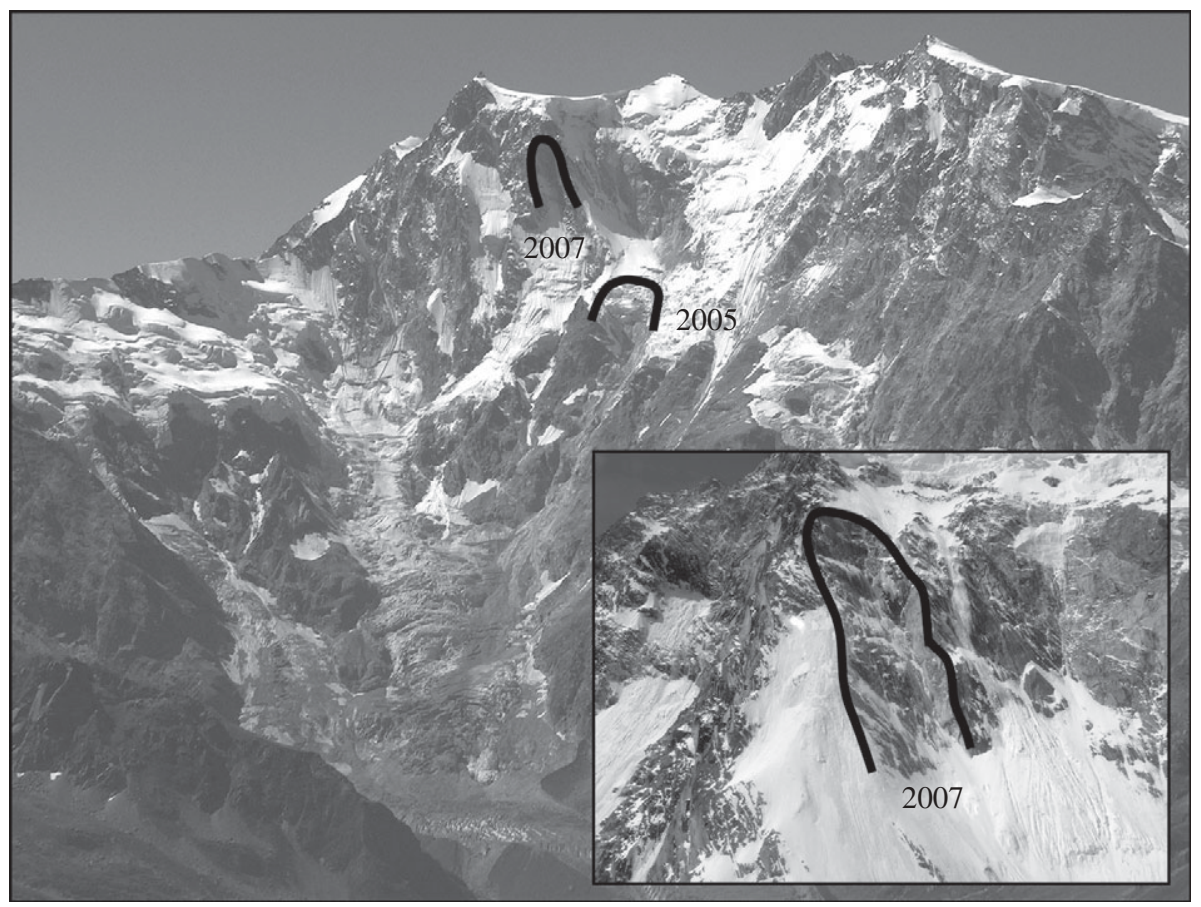

Figure 12. Monte Rosa east face, indicating the sources of the 2005 ice avalanche and the 2007 rock avalanche. The inset close-up photo shows the scar of the 2007 failure 3 months after the event, with layering parallel to the slope (photos taken by L. Fischer \& C. Huggel).

The 2005 event was a large ice avalanche $\left(1.1 \times 10^{6} \mathrm{~m}^{3}\right)$ that initiated from a steep glacier terminating at $3500 \mathrm{~m}$ a.s.l. and reached the foot of the face, where a large supraglacial lake had formed in 2002, but had drained in 2003 (figure 12). Had the lake still existed, the avalanche would have generated a displacement wave with catastrophic consequences for the downstream community of Macugnaga. The avalanche occurred at night, which probably prevented injuries to tourists who often spend daylight hours on the pasture that was affected.

The 2007 event was a rock avalanche that detached from the exposed bedrock at approximately $4000 \mathrm{~m}$ a.s.l. near the top of the east face of Monte Rosa (figure 12). It involved about $0.3 \times 10^{6} \mathrm{~m}^{3}$ of rock that fell to the base of the slope, again impacting the area of the former supraglacial lake.

Two meteorological stations at elevations greater than $3000 \mathrm{~m}$ are near Monte Rosa - a station at Testa Grigia, Italy (3488 ma.s.l.), $15 \mathrm{~km}$ to the west; and the Swiss station at Gornergrat (3130 ma.s.l.), $9 \mathrm{~km}$ to the northwest. The Testa Grigia station has a temperature record for 1951-2000, but measurements unfortunately were not continued after 2000, while the station at Gonergrat came into operation only in 1994 and has been working properly since then. Based on these data, temperature extrapolations yield a MAAT of -5 to $-6^{\circ} \mathrm{C}$ at the lower end of the ice avalanche failure zone, suggesting a cold glacier front, but probably polythermal to temperate conditions at some distance behind the front. Previous 


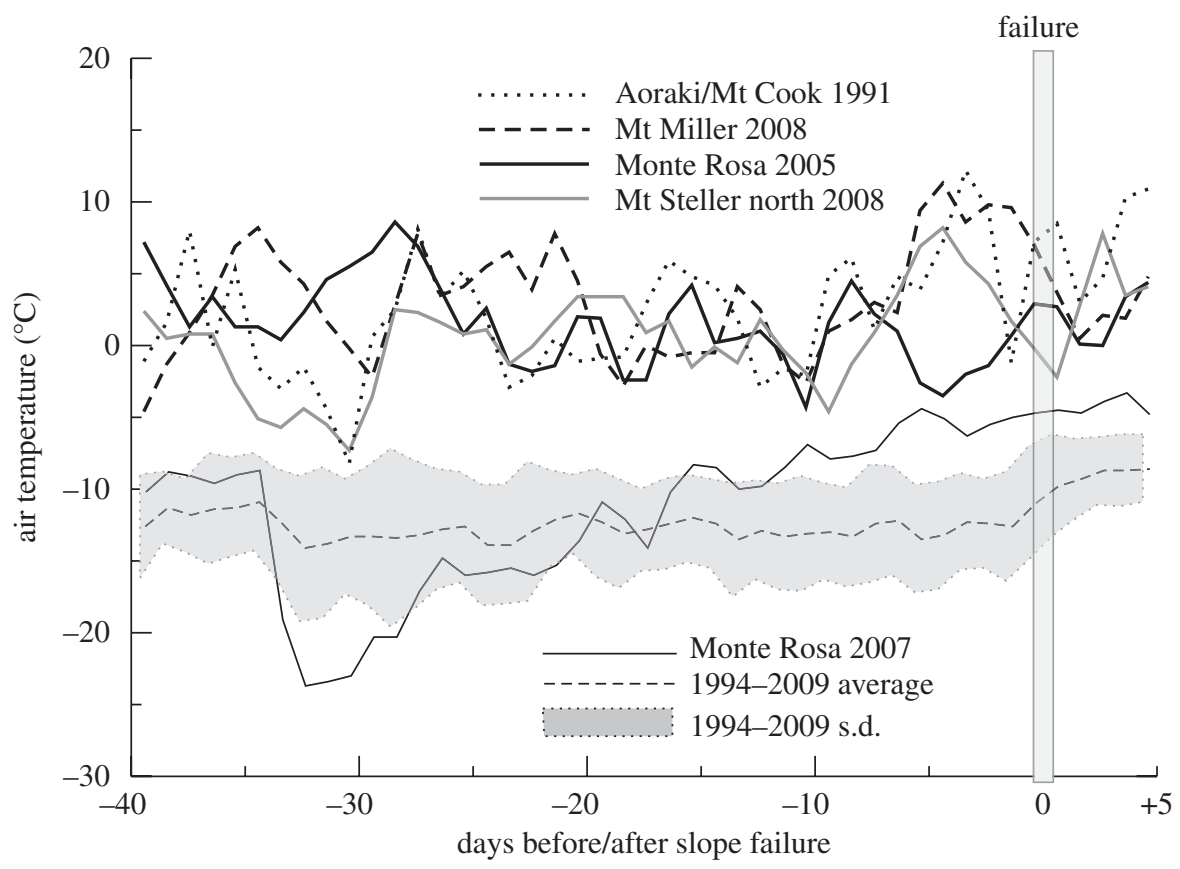

Figure 13. Summary of air temperatures up to 40 days prior to the failures. All temperatures are extrapolated to the elevation of the respective failure zone, using regional lapse rates $\left(0.55^{-}\right.$ $\left.0.65^{\circ} \mathrm{C} 100 \mathrm{~m}^{-1}\right)$. Air temperatures for all landslides except the April 2007 Monte Rosa slide fluctuated around the freezing point, with extended warm periods. Several of the slides show a rapid drop in temperature after a warm period and immediately before failure. The 2007 Monte Rosa slide occurred under considerably lower temperatures than the other slides. However, the last approximately 10 days before this failure are over 1 s.d. above the 1994-2009 mean.

studies show that the lower limit of permafrost is at about $3000 \mathrm{~m}$ a.s.l. on north- to northeast-facing slopes, and up to $500 \mathrm{~m}$ higher on east-facing sections (Zgraggen 2005; Fischer et al. 2006; Huggel 2009).

Estimates of MAGST for the 2007 rock-slope failure, based on data from the aforementioned meteorological stations and rock temperature loggers deployed on the east face (Zgraggen 2005) suggest temperatures of about $-6{ }^{\circ} \mathrm{C}$. These conditions compare with those on Mt Steller south, but unlike Mt Steller, the Monte Rosa site was not thermally perturbed by the overlying glacier ice. A more likely destabilization factor is the enormous loss of ice at the base of the failure zone over the past 20 years with a volume of more than $20 \times 10^{6} \mathrm{~m}^{3}$, which probably caused significant changes to the stress and temperature fields (Fischer et al. submitted $b$ ). In addition, the dip of the foliation in the gneissic bedrock is parallel to the surface slope, adversely affecting slope stability.

Weather in the days and weeks prior to the landslides was very different for the 2005 and 2007 slides. Several warm periods of 5-10 days duration occurred in June and July 2005. Temperatures rose to $5^{\circ} \mathrm{C}$ above the 1994-2009 average (of the Gornergrat station record). The warm periods were interrupted by temperature drops, with several freeze-thaw cycles during the 20 days before the failure (figure 13). After the last freezing event 4 days before the landslide, 


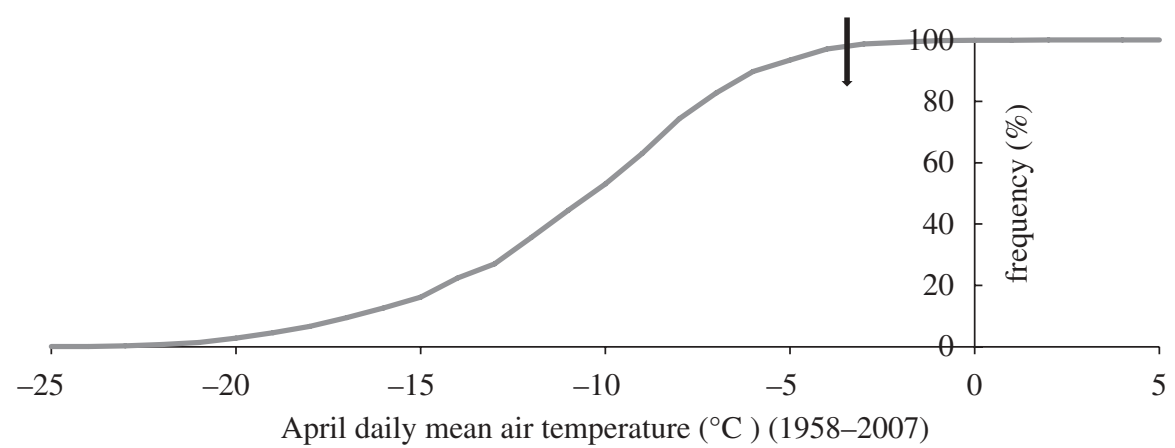

Figure 14. Frequency distribution of daily mean temperatures for April 1958-2007, Jungfraujoch station (3580 ma.s.l.). The mean temperature for April 2007 was $5^{\circ} \mathrm{C}$ warmer than that of the previous 49 years. The temperature of $-3.5^{\circ} \mathrm{C}$ (black arrow) for 20 April 2007 (1 day before failure) plots in the 98th-99th percentile of the long-term record.

temperatures again increased to $5^{\circ} \mathrm{C}$ on the day of failure. Much melt water was produced during the warm periods and possibly penetrated to the base of the steep glacier, lowering the strength at its contact with the underlying bedrock. The repeated cycles of melt and refreezing may have also destabilized the bedrock.

Temperatures in April 2007 were extraordinarily warm in central Europe, producing a spring heat wave. April temperatures at Jungfraujoch at $3580 \mathrm{~m}$ a.s.l. were $5^{\circ} \mathrm{C}$ warmer than the mean of the previous 49 years. The temperature of $-3.5^{\circ} \mathrm{C}, 1$ day before the landslide, is in the 98th-99th percentile of the long-term April record (for Jungfraujoch available since 1958; figure 14). The Jungfraujoch climate record is highly correlated to the record at the Gornergrat station, which is the nearest station above $3000 \mathrm{~m}$ a.s.l. to the failure site, and which reveals interesting thermal patterns during the weeks before the failure. Exactly 1 month prior to the landslide, temperatures dropped to an estimated $-24^{\circ} \mathrm{C}$ at the failure site, which is about $10^{\circ} \mathrm{C}$ lower than the long-term average (figure 13). After this unusually cold period, temperature rose steadily to approximately $-5^{\circ} \mathrm{C}$ near the date of the failure. However, radiation on the east face of Monte Rosa in April is high and cloud cover was generally low in April 2007. We thus infer that snow and ice melted at the surface in spite of the subfreezing air temperature. In addition, it is possible that thermal energy during particularly warm summer months in 2003 and 2006, when the $0^{\circ} \mathrm{C}$ isotherm was above $4000 \mathrm{~m}$ a.s.l., penetrated into bedrock some metres deep at the level of the rock-slope failure.

\section{Future trends based on regional climate model (RCM) simulations}

Several studies indicate that warm extremes increased during the twentieth century (Alexander et al. 2006), and are likely to further increase during the twenty-first century (Beniston et al. 2007). The Intergovernmental Panel on Climate Change defines an 'extreme weather event' as a rare event lying outside the 90th, 95th or 99th (or 10th, 5th and 1st, respectively) percentile of a statistical reference distribution (Trenberth et al. 2007). Extreme events can also be defined in terms of their intensity or severity of damage (Beniston et al. 2007). 
In terms of temperature, analyses of trends often use indices such as the number of daily maximum or minimum temperature, or monthly to seasonal maximum temperatures (Schär et al. 2004; Aguilar et al. 2005).

Here, we consider whether unusually warm periods of a few days to a couple of weeks might increase in the future. We explore this issue using the results from the most recent RCM simulations. RCMs are currently among the most comprehensive tools to project climate on regional scales. The recently completed European Union programme ENSEMBLES (van der Linden \& Mitchell 2009) ran a large number of RCMs over Europe to provide the climate-impacts community with an ensemble of state-of-the-art regional climate simulations. To evaluate and express uncertainty, the ENSEMBLES simulations include a large number of RCMs, driven by different general circulation models (GCMs) with identical boundary settings. The RCMs were run with 25 or $50 \mathrm{~km}$ horizontal resolution for the period 1951-2050 (some until 2100). The Special Report on Emission Scenarios (SRES) Scenario A1B (Nakicenovic \& Swart 2000) was applied for all model runs. Scenario A1B represents future conditions of rapid economic growth and introduction of more efficient technologies, with a balance between fossil and non-fossil energy production.

For the present study, we analysed results for air temperature $2 \mathrm{~m}$ above the ground from eight ENSEMBLES RCM simulations. We chose a mix of different $\mathrm{RCMs}$, driven with different GCMs, to provide a representative selection.

- HIRHAM_ARPEGE (from Danish Meteorological Institute; DMI),

- HIRHAM ECHAM5 (from Danish Meteorological Institute; DMI),

- ETHZ-CLM_HADCM3Q (from Swiss Federal Institute of Technology; ETHZ),

- HIRHAM_HADCM3Q (from Norwegian Meteorological Institute; METNO),

- HIRHAM BCM (from Norwegian Meteorological Institute; METNO),

- HIRAC BCM (from Swedish Meteorological Institute; SMHI), and

— HIRHAM_HADCM3Q (from Swedish Meteorological Institute; SMHI).

The first part of each acronym represents the RCM, while the second part refers to the driving GCM.

Mean daily temperature results were analysed for anomalously warm temperature events both in the past and the future. The analysis is based on one grid box that represents the longitudes and latitudes of the Jungfrau region. The Jungfrau region was chosen based on the availability of long-term highelevation observational time series (since 1958) from the Swiss Federal Institute of Meteorology and Climatology (MeteoSwiss), which enables performance analysis and de-biasing of the RCM simulations. Typically, measured air temperatures at high-altitude climate stations are highly correlated. The temperature records at the Jungfraujoch and Gornergrat stations have a correlation coefficient of 0.98 for the common period of record. Therefore, we assume that the Jungfraujoch data are representative also for conditions at or near Gornergrat (including Monte Rosa).

A horizontal resolution of $25 \mathrm{~km}$, which is now the standard for many RCM simulations, is too coarse to represent the topography of a high-mountain region realistically. The selected grid box is referenced to an elevation of 
Table 1. Summary of changes (expressed as factor) in warm air-temperature anomalies between 1951-2000 and 2001-2050, based on eight RCMs. A factor of 1 means no change is projected between the two time periods, a factor of 10 foresees a 10 times increase for the future 2001-2050 period. The column 'bias' refers to the difference between the observed mean annual temperature of Jungfraujoch for the available time period 1960-2000 and the respective temperature of the RCM time series.

\begin{tabular}{lllll}
\hline RCM & $\Delta 30$ day events & $\Delta 10$ day events & $\Delta 5$ day events & bias $\left({ }^{\circ} \mathrm{C}\right)$ \\
\hline DMI-HIRHAM5_ARPEGE & 5.5 & 1 & 0.9 & -5.5 \\
DMI-HIRHAM_ECHAM5 & $\mathrm{a}$ & $\mathrm{a}$ & $\mathrm{a}$ & -3 \\
ETHZ-CLM_HADCM3Q & 10 & 2.2 & 1.5 & -3 \\
METNO-HIRHAM_HADCM3Q & $\mathrm{a}$ & 2.5 & 1.2 & -4.5 \\
METNO-HIRHAM_BCM & $\mathrm{a}$ & $\mathrm{a}$ & $\mathrm{a}$ & -1 \\
SMH-HIRAC_BCM & 8 & 3.7 & 2.1 & -2.5 \\
SMH-HIRHAM_HADCM3Q & $\mathrm{a}$ & 1.7 & 3.7 & -6.5 \\
MPI-REMO_ECHAM5 & $\mathrm{a}$ & 8.3 & 2.2 & -5 \\
\hline
\end{tabular}

${ }^{a}$ No event indicated either in the past or in the future.

2244 ma.s.l., and therefore needed to be adjusted to the level of Jungfraujoch at $3580 \mathrm{~m}$ a.s.l., applying a basic lapse-rate correction of $0.6^{\circ} \mathrm{C} 100 \mathrm{~m}^{-1}$ (as an average over the year; Rolland 2003) to adjust the air temperature of the RCM grid box with an elevation of $2244-3580 \mathrm{~m}$, the elevation of the Jungfraujoch climate station.

In addition to the elevation adjustment, we applied a bias correction to each RCM time series (Salzmann et al. 2007a,b). The bias relates to the difference between the mean annual air temperature observed at Jungfraujoch for the available time period 1960-2000 and the respective temperature of the RCM time series (table 1). The bias correction involves only one temperature value per RCM; different values for different seasons or months were not used.

The following analyses are based on the RCM time series with elevation adjustment and bias correction as described above. We studied eight RCM time series to identify periods with air temperature continuously exceeding a threshold of $+5^{\circ} \mathrm{C}$ for periods of 5,10 and 30 days, thus representing significant melting conditions. These thresholds are based on the case studies described above, where warm air-temperature anomalies of many days duration were observed prior to each failure. We analysed the change in frequency of these events for the period 2001-2050 when compared with the reference period 1951-2000. The results are shown in table 1.

Results from the eight models show a clear increase in the frequency of warm air-temperature events in the next several decades compared with the second half of the twentieth century (table 1). For a matrix comprising eight models and three event types, only one model (DMI-HIRHAM5_ARPEGE) produces a slight decrease (approx. 10\%) of the 5 day events. The differences among the model outputs are large, but most models show increases in frequency of extreme events of about 1.5-4 times. Large increases in the frequency of warm extremes, by a factor of $8-10$, are projected by three models. In two of these three cases, the increase is for 30 day events. On the other hand, five models show no 30 day extreme warm events, either for the past or the future. 


\section{Discussion and conclusions}

Our analysis of temperature records days and weeks before several large high-mountain rock and ice avalanches is a start in documenting this littleinvestigated aspect of slope instability. A clear predictive thermal trigger is scarcely discernable for all events. However, examination of the ensemble of temperature conditions prior to failure for our case studies suggests that some thermal patterns are repeated at locations as different and distant from one another as Alaska, New Zealand and the European Alps: (i) unusually warm temperatures over several days during the weeks or days before failure and (ii) sudden drops of temperatures, typically below freezing, after warm periods and hours to days before failure.

All the studied events had warm temperatures, far above freezing prior to failure, except the 2007 Monte Rosa landslide. In most of the cases, temperatures above freezing during summer months are not exceptional, although the observed temperatures were far above normal. At Mt Cook, for example, the peak temperature 3 days before failure was $8.5^{\circ} \mathrm{C}$ above the long-term average. Temperatures in the days before the April 2007 Monte Rosa rock slide were up to $4-5^{\circ} \mathrm{C}$ above 1 s.d. of the long-term record. Such unusually warm periods enhance melt of surface snow and ice. The water generated by melting can infiltrate rock slopes via fractures and joints, increasing hydrostatic pressures and thus reducing shear strength (Huggel et al. 2008a). Photographs taken after the 2008 Mt Steller north slides show large amounts of water on the landslide scar, and some of the water appears to have seeped from bedrock discontinuities. Melt water can also penetrate to the base of steep glaciers and reduce their resistance to failure.

Temperature pattern (ii) has been inferred at the sites of the Mt Cook and the 2005 and $2008 \mathrm{Mt}$ Steller events (Huggel 2009), as well as at the site of a rock slide in permafrost in the eastern Swiss Alps, not discussed here further (Fischer et al. submitted $a$ ). It did not occur, however, at the 2005 Monte Rosa ice avalanche and the 2007 Monte Rosa landslide. A sudden lowering of temperature may favour slope failure by refreezing the surface following infiltration of melt water into bedrock during the preceding warm period. Such 'lock-off' situations are difficult to quantify owing to a lack of on-site measurements with piezometers and other instruments (Watson et al. 2004; Willenberg et al. 2008), but have been invoked in similar conditions (Fischer et al. submitted $a, b$ ). In this context, we should also consider the importance of rainfall or melt of fresh snow as potential sources of infiltrating water and slope destabilization. Accurate measurements of precipitation at sites of high-mountain slope failures are rare and difficult to acquire because of the large spatial variation in precipitation in areas of high relief. The Gornergrat meteorological station is less than $10 \mathrm{~km}$ from Monte Rosa, but we did not use its precipitation data for this study because precipitation is highly variable in this region (Machguth et al. 2006). There is more certainty at Mt Cook, where total precipitation of 48 and $11 \mathrm{~mm}$, respectively, was measured windward and leeward of Mt Cook in the week prior to failure; this amount is not significant in a region with common, much larger daily precipitation.

Another climate variable that was not examined in this study, but may have an important effect on surface warming and melting, is radiation. Short-wave radiation constitutes a major portion of the energy available for melt during 


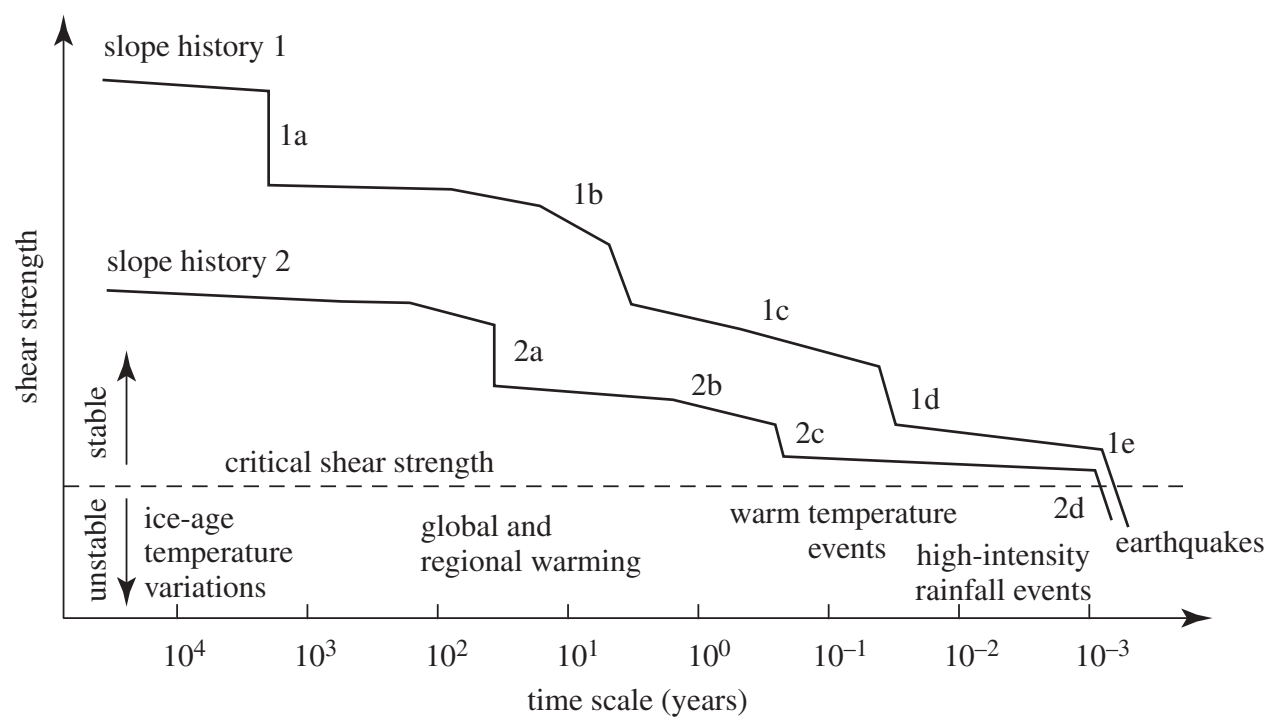

Figure 15. A hypothetical sketch of two slope histories, shown over a relevant period of time prior to slope failure. The dashed line indicates the critical shear strength threshold below which the slope is unstable and failure would occur. Both slope histories are characterized by processes that produce a gradual decrease in shear strength over long periods of time (e.g. warming at the close of the Pleistocene) and abrupt reductions in shear strength (e.g. 1a, d, e; 2a, c, d) due, for example, to seismic activity. Slope 2 has a lower initial shear strength due, for example, to rock type or structure. Processes that can cause abrupt reductions in shear strength, including warm extremes or high-intensity rainfall, only act as slope failure triggers if the shear strength is sufficiently low.

summer and may be close to $200 \mathrm{Wm}^{-2}$ in alpine conditions (Oerlemans 2001). In several of the cases presented here, short-wave radiation may have played a role in melting snow and ice. For instance, air temperatures reached only $-5^{\circ} \mathrm{C}$ before the failure at the site of the 2007 Monte Rosa landslide, but clear-sky conditions resulted in high short-wave radiation that may have melted surface snow, with possible infiltration of water into the highly fractured bedrock. Radiation may also have played a role in the 2008 Steller and Miller landslides.

Our analysis concentrated on temperature aspects of large high-mountain slope failures, but this is only one component of a highly complex physical system that, in response to gradual and sudden changes in external and internal controls, produces a slope failure. Several geological factors, including structure and rock type, glaciation, permafrost, topography and seismicity, are important determinants of slope stability in this environment. It is fundamental in this context to consider the time scales involved in causative and trigger factors. Figure 15 shows two hypothetical histories of slopes prior to failure. Slope 1 has a higher initial shear strength corresponding, for example, to more stable geological or topographic conditions. Geology and topography are typical predisposing factors. The histories of both slopes are characterized by processes that gradually reduce their shear strength over periods of decades to millennia. Short-term events, operating over days to weeks, such as warm extremes, high-intensity rainfall or earthquakes, can rapidly reduce the strength of the slope. However, 
these events may not necessarily trigger failure, depending on their impact and the shear strength of the slope when they occur. Slope failure only occurs if the potential triggering event reduces the shear strength below a critical threshold. These events will trigger a landslide only if slope stability is already low and near the threshold of failure.

The concept of effective time scales is particularly important when considering bedrock permafrost and slope stability. Thermal perturbations resulting from twentieth century warming, for instance, has now penetrated to depths of a few decametres in high-rock slopes (Haeberli et al. 1997; Noetzli et al. 2007), whereas short warm extremes may have an effect at a few metres depth only one or several years later. Open fractures, however, can facilitate infiltration of water into rock slopes and thus contribute to a much more immediate effect on slope stability.

Based on an analysis of the ENSEMBLE RCM simulations, we have found that short periods with very high temperatures may increase 1.5-4 times in the next several decades compared with the 1951-2000 reference period. Shortduration warm periods may produce a critical input of water into slopes. The projected increase in extended warm periods of up to 1 month is also of concern because such events can lead to substantial thermal perturbation of subsurface hydrology.

The large range in the RCM results suggests that it is difficult to provide accurate regional climate projections, even when using the same SRES scenario and the most advanced RCMs. Nevertheless, the projected increase in the frequency of short-term temperature extremes is consistent with earlier findings on heat waves on the global (Meehl et al. 2007) and European scales at the end of the twenty-first century based on the earlier generation of Prediction of Regional Scenarios and Uncertainties for Defining European Climate Change Risks and Effects (PRUDENCE) RCMs (Beniston et al. 2007). Although not investigated here, several studies have documented an increase in warm extremes, including summer heat waves, during the twentieth century on global and regional scales (Alexander et al. 2006; Hegerl et al. 2007). However, the limited availability of high-quality and homogenized climate station data is an important constraint on a more detailed analyses of extreme events (Hegerl et al. 2007).

We have performed the analysis of future warm extremes for the Alps, motivated by the recent completion of the ENSEMBLES project that made RCM data available for a range of models and thus allows for a better consideration of uncertainties involved. Results found for Europe cannot directly be transformed to our other study regions in Alaska and New Zealand. However, global assessments show similar tendencies (Meehl et al. 2007), and we therefore assume that our conclusions are broadly valid for these regions as well. Furthermore, similar RCM programmes like ENSEMBLES are currently ongoing in other parts of the world (North American Regional Climate Change Assessment Program, NARCCAP (Mearns et al. 2009); Regional Climate Change Scenarios for South America, CREAS (Marengo \& Ambrizzi 2006)). In addition, with the World Climate Research Programme's Coordinated Regional Climate Downscaling Experiment (CORDEX) initiative, RCM simulations will be available for all continents and allow regional-scale scenario analysis worldwide.

Several aspects of the role of warm extremes in high-mountain slope stability remain unresolved, but this study hopefully will stimulate further discussion and research. As argued in figure 15, not every warm extreme will trigger a 
large slope failure. However, we think that large slope failures will increase in temperature-sensitive, high-mountain areas as the number of warm extreme events increases.

The landslides described in the case studies did not cause any major damage to people or infrastructure, partly owing to fortunate circumstances, partly owing to the remote location of the landslides. In densely populated and developed mountain regions such as the European Alps, however, serious consequences have to be considered from large slope failures. Cascading processes (e.g. landslides impacting natural or artificial lakes producing outburst floods) are of particular concern. With the Monte Rosa case study, it has been indicated that similar landslides as in 2005/2007 would probably have resulted in a major disaster had they occurred during the existence of a large glacier lake in 2002/2003.

We gratefully acknowledge photographs and satellite images provided by Manuela Uhlmann, Bruce Molnia, Ruedi Homberger, Isabelle Gärtner-Roer, of the Earth Resources Observation and Science Center, US Geological Survey, and further information by Gianni Mortara. Very useful comments by John Clague and an anonymous reviewer, as well as by the editor Bill McGuire, are highly appreciated.

\section{References}

Aguilar, E. et al. 2005 Changes in precipitation and temperature extremes in Central America and northern South America, 1961-2003. J. Geophys. Res. 110, D23107. (doi:10.1029/ 2005JD006119)

Alean, J. 1985 Ice avalanches, some empirical information about their formation and reach. J. Glaciol. 31, 324-333.

Alexander, L. V. et al. 2006 Global observed changes in daily climate extremes of temperature and precipitation. J. Geophys. Res. 111, D05109. (doi:10.1029/2005JD006290)

Allen, S. K., Gruber, S. \& Owens, I. 2009 Exploring steep bedrock permafrost and its relationship with recent slope failures in the Southern Alps of New Zealand. Permafrost Periglac. Process. 20, 345-356. (doi:10.1002/ppp.658)

Arsenault, A. M. \& Meigs, A. J. 2005 Contribution of deep-seated bedrock landslides to erosion of a glaciated basin in southern Alaska. Earth Surf. 30, 1111-1126. (doi:10.1002/esp.1265)

Barla, G., Dutto, F. \& Mortara, G. 2000 Brenva glacier rock avalanche of 18 January 1997 on the Mount Blanc range, northwest Italy. Landslide News 13, 2-5.

Beniston, M. et al. 2007 Future extreme events in European climate, an exploration of regional climate model projections. Clim. Change 81, 71-95. (doi:10.1007/s10584-006-9226-z)

Caplan-Auerbach, J. \& Huggel, C. 2007 Precursory seismicity associated with frequent, large ice avalanches on Iliamna volcano, Alaska, USA. J. Glaciol. 53, 128-140. (doi:10.3189/ 172756507781833866)

Clague, J. J. \& Evans, S. G. 2000 A review of catastrophic drainage of moraine-dammed lakes in British Columbia. Q. Sci. Rev. 19, 1763-1783. (doi:10.1016/S0277-3791(00)00090-1)

Cox, S. C. \& Allen, S. K. 2009 Vampire rock avalanches of January 2008 and 2003, Southern Alps, New Zealand. Landslides 6, 161-166. (doi:10.1007/s10346-009-0149-4)

Fischer, L. \& Huggel, C. 2008 Methodical design for stability assessments of permafrost-affected high-mountain rock walls. In Proc. 9th Int. Conf. on Permafrost, University of Alaska, Fairbanks (eds D. L. Kane \& K. M. Hinkel), pp. 439-444.

Fischer, L., Kääb, A., Huggel, C. \& Noetzli, J. 2006 Geology, glacier retreat and permafrost degradation as controlling factors of slope instabilities in a high-mountain rock wall, the Monte Rosa east face. Nat. Hazards Earth Syst. Sci. 6, 761-772.

Fischer, L., Amann, F., Moore, J. \& Huggel, C. Submitted $a$ The 1988 Tschierva rock avalanche (Piz Morteratsch, Switzerland): an integrated approach to periglacial rock slope stability assessment. Eng. Geol.

Phil. Trans. R. Soc. A (2010) 
Fischer, L., Eisenbeiss, H., Kääb, A., Huggel, C. \& Haeberli, W. Submitted $b$ Detecting topographic changes in steep high-mountain flanks using combined repeat airborne LiDAR and aerial optical imagery - a case study on climate-induced hazards at Monte Rosa east face, Italian Alps. Permafrost Periglac. Process.

Gruber, S. \& Haeberli, W. 2007 Permafrost in steep bedrock slopes and its temperaturerelated destabilization following climate change. J. Geophys. Res. 112, F02S18. (doi:10.1029/ 2006JF000547)

Gruber, S. Hoelzle, M. \& Haeberli, W. $2004 a$ Permafrost thaw and destabilization of Alpine rock walls in the hot summer of 2003. Geophys. Res. Lett. 31, L13504. (doi:10.1029/2004GL020051)

Gruber, S. Hoelzle, M. \& Haeberli, W. 2004b Rock-wall temperatures in the Alps, modelling their topographic distribution and regional differences. Permafrost Periglac. Process. 15, 299-307. (doi:10.1002/ppp.501)

Haeberli, W. \& Hohmann, R. 2008 Climate, glaciers and permafrost in the Swiss Alps 2050, scenarios, consequences and recommendations. In Proc. 9th Int. Conf. on Permafrost, University of Alaska, Fairbanks (eds D. L. Kane \& K. M. Hinkel), pp. 607-612.

Haeberli, W., Wegmann, M. \& Vonder Mühll, D. 1997 Slope stability problems related to glacier shrinkage and permafrost degradation in the Alps. Eclogae. Geol. 90, 407-414.

Haeberli, W., Käab, A., Paul, F., Chiarle, M., Mortara, G., Mazza, A. \& Richardson, S. 2002 A surge-type movement at Ghiacciaio del Belvedere and a developing slope instability in the east face of Monte Rosa, Macunaga, Italian Alps. Norw. Geogr. Tidsskr. 56, 104-111. (doi:10.1080/002919502760056422)

Haeberli, W., Huggel, C., Kääb, A., Polkvoj, A., Zotikov, I. \& Osokin, N. 2003 Permafrost conditions in the starting zone of the Kolka-Karmadon rock/ice slide of 20 September 2002 in North Osetia (Russian Caucasus). In Extended Abstracts on Current Research and Newly Available Information 8th Int. Conf. on Permafrost, University of Zurich, Switzerland (W. Haeberli \& D. Brandova), pp. 21-25.

Harris, C. et al. 2009 Permafrost and climate in Europe, monitoring and modelling thermal, geomorphological and geotechnical responses. Earth Sci. Rev. 92, 117-171. (doi:10.1016/ j.earscirev.2008.12.002)

Hegerl, G., Zwiers, F., Braconnot, P., Gillett, N., Luo, Y., Marengo Orsini, J., Nicholls, N., Penner, J. \& Stott, P. 2007 Understanding and attributing climate change. In Climate change 2007, the physical science basis, Contribution of working group I to the fourth assessment report of the intergovernmental panel on climate change (eds S. Solomon, D. Qin, M. Manning, Z. Chen, M. Marquis, K. B. Averyt, M. Tignor \& H. L. Miller), pp. 663-745. Cambridge, UK: Cambridge University Press.

Heim, A. 1932 Bergsturz und Menschenleben. Beiblatt zur Vierteljahrschrift der Naturorschenden Gesellschaft in Zurich, 77.

Huggel, C. 2009 Recent extreme slope failures in glacial environments, effects of thermal perturbation. Quat. Sci. Rev. 28, 1119-1130. (doi:10.1016/j.quascirev.2008.06.007)

Huggel, C., Haeberli, W., Kaab, A., Bieri, D. \& Richardson, S. 2004 An assessment procedure for glacial hazards in the Swiss Alps. Can. Geotech. J. 41, 1068-1083. (doi:10.1139/t04-053)

Huggel, C., Caplan-Auerbach, J., Waythomas, C. F. \& Wessels, R. L. 2007 Monitoring and modeling ice-rock avalanches from ice-capped volcanoes, a case study of frequent large avalanches on Iliamna Volcano, Alaska. J. Volcanol. Geotherm. Res. 168, 114-136. (doi:10.1016/ j.jvolgeores.2007.08.009)

Huggel, C., Caplan-Auerbach, J., Gruber, S., Molnia, B. \& Wessels, R. 2008a The 2005 Mt. Steller, Alaska, rock-ice avalanche, a large slope failure in cold permafrost. In Proc. 9th Int. Conf. on Permafrost, University of Alaska, Fairbanks (eds D. L. Kane, \& K. M. Hinkel). pp. 747-752.

Huggel, C., Caplan-Auerbach, J. \& Wessels, R. 2008b Recent extreme avalanches, triggered by climate change. Eos, Trans. AGU 89, 469-470. (doi:10.1029/2008EO470001)

Jibson, R. W., Harp, E. L., Schulz, W. \& Keefer, D. K. 2006 Large rock avalanches triggered by the M 7.9 Denali Fault, Alaska, earthquake of 3 November 2002. Eng. Geol. 83, 144-160. (doi:10.1016/j.enggeo.2005.06.029) 
Kääb, A., Reynolds, J. M. \& Haeberli, W. 2005 Glaciers and permafrost hazards in high mountains. In Global change and mountain regions-an overview of current knowledge (eds U. M. Huber, H. K. H. Burgmann \& M. A. Reasoner), pp. 225-234. Dordrecht, The Netherlands: Springer.

Legros, F. 2002 The mobility of long-runout landslides. Eng. Geol. 63, 301-331. (doi:10.1016/ S0013-7952(01)00090-4)

Machguth, H., Eisen, O., Paul, F. \& Hoelzle, M. 2006 Strong spatial variability of snow accumulation observed with helicopter-borne GPR on two adjacent Alpine glaciers. Geophys. Res. Lett. 33, L13503. (doi:10.1029/2006GL026576)

Marengo, J. A. \& Ambrizzi, T. 2006 Use of regional climate models in impacts assessments and adaptation studies from continental to regional and local scales - the CREAS (Regional Climate Change Scenarios for South America) initiative in South America. In Proc. 8 ICSHMO, Foz do Iguaçu, Brazil, 24-28 April 2006, INPE, pp. 291-296.

McSaveney, M. J. 2002 Recent rockfalls and rock avalanches in Mount Cook national park, New Zealand. In Catastrophic landslides, effects, occurrence and mechanisms (eds S. G. Evans \& J. V. DeGraff). Reviews in Engineering Geology, pp. 35-70. Boulder, CO: Geological Society of America.

Mearns, L. O., Gutowski, W., Jones, R., Leung, R., McGinnis, S., Nunes, A. \& Qian, Y. 2009 A regional climate change assessment program for North America. Eos Trans. AGU 90, 311. (doi:10.1029/2009EO360002)

Meehl, G. et al. 2007 Global climate projections. In Climate change 200\%, the physical science basis, Contribution of working group I to the fourth assessment report of the intergovernmental panel on climate change (eds S. Solomon, D. Qin, M. Manning, Z. Chen, M. Marquis, K. B. Averyt, M. Tignor \& H. L. Miller). Cambridge, UK: Cambridge University Press.

Nakicenovic, N. \& Swart, R. 2000 Special report on emissions scenarios, a special report of working group III of the Intergovernmental Panel on Climate Change. Cambridge, UK: Cambridge University Press.

Noetzli, J., Gruber, S., Kohl, T., Salzmann, N. \& Haeberli, W. 2007 Three-dimensional distribution and evolution of permafrost temperatures in idealized high-mountain topography. J. Geophys. Res. 112, F02S13. (doi:10.1029/2006JF000545)

Oerlemans, J. 2001 Glaciers and climate change. Lisse, The Netherlands: A.A. Balkema Publishers.

Quincey, D. J. \& Glasser, N. F. 2009 Morphological and ice-dynamical changes on the Tasman Glacier, New Zealand, 1990-2007. Global Planet. Change 68, 185-197. (doi:10.1016/ j.gloplacha.2009.05.003)

Rolland, C. 2003 Spatial and seasonal variations of air temperature Lapse rates in Alpine regions. J. Climate 16, 1032-1046. (doi:10.1175/1520-0442(2003)016<1032:SASVOA > 2.0.CO;2)

Röthlisberger, H. 1987 Sliding phenomena in a steep section of Balmhorngletscher, Switzerland. J. Geophys. Res. 92, 8999-9014. (doi:10.1029/JB092iB09p08999)

Salzmann, N., Frei, C., Vidale, P. \& Hoelzle, M. $2007 a$ The application of regional climate model output for the simulation of high-mountain permafrost scenarios. Global Planet. Change 56, 188-202. (doi:10.1016/j.gloplacha.2006.07.006)

Salzmann, N., Nötzli, J., Hauck, C., Gruber, S., Hoelzle, M. \& Haeberli, W. $2007 b$ Ground surface temperature scenarios in complex high-mountain topography based on regional climate model results. J. Geophys. Res. 112, F02S12. (doi:10.1029/2006JF000527)

Schär, C., Vidale, P. L., Lüthi, D., Frei, C., Häberli, C., Liniger, M. A. \& Appenzeller, C. 2004 The role of increasing temperature variability in European summer heatwaves. Nature 427, 332-336. (doi:10.1038/nature02300)

Sosio, R., Crosta, G. \& Hungr, O. 2008 Complete dynamic modeling calibration for the Thurwieser rock avalanche (Italian Central Alps). Eng. Geol. 100, 11-26. (doi:10.1016/j.enggeo. 2008.02.012)

Suter, S., Laternser, M., Haeberli, W., Frauenfelder, R. \& Hoelzle, M. 2001 Cold firn and ice of high-altitude glaciers in the Alps, measurements and distribution modelling. J. Glaciol. 47, 85-96. (doi:10.3189/172756501781832566)

Tebaldi, C., Hayhoe, K., Arblaster, J. M. \& Meehl, G. A. 2006 Going to the extremes. Clim. Change 79, 185-211. (doi:10.1007/s10584-006-9051-4) 
Trenberth, K. et al. 2007 Observations, surface and atmospheric climate change. In Climate change 200\%, the physical science basis, Contribution of working group I to the fourth assessment report of the intergovernmental panel on climate change (eds S. Solomon, D. Qin, M. Manning, Z. Chen, M. Marquis, K. B. Averyt, M. Tignor \& H. L. Miller), pp. 235-336. Cambridge, UK: Cambridge University Press.

van der Linden, P. \& Mitchell, J. 2009 ENSEMBLES, climate change and its impacts, summary of research and results from the ENSEMBLES project. Met Office Hadley Centre, Exeter, UK.

Watson, A. D., Moore, D. P. \& Stewart, T. W. 2004 Temperature influence on rock slope movements at Checkerboard Creek. In Int. Symp. on Landslides, pp. 1293-1298. Rio de Janeiro, Brazil: Balkema.

Wegmann, M., Gudmundsson, G. H. \& Haeberli, W. 1998 Permafrost changes in rock walls and the retreat of Alpine glaciers, a thermal modelling approach. Permafrost Periglac. Process. 9, 23-33. (doi:10.1002/(SICI)1099-1530(199801/03)9:1<23::AID-PPP274>3.0.CO;2-Y)

Willenberg, H., Evans, K. F. Eberhardt, E., Spillmann, T. \& Loew, S. 2008 Internal structure and deformation of an unstable crystalline rock mass above Randa (Switzerland): part II-threedimensional deformation patterns. Eng. Geol. 101, 15-32. (doi:10.1016/j.enggeo.2008.01.016)

Zgraggen, A. 2005 Measuring and modeling rock surface temperatures in the Monte Rosa East face. Master thesis, ETH Zurich University of Zurich, Zurich, Switzerland. 